\title{
Investigation of the Optical, Physical, and Chemical Interactions between Diammonium Hydrogen Phosphate (DAP) and Pigments
}

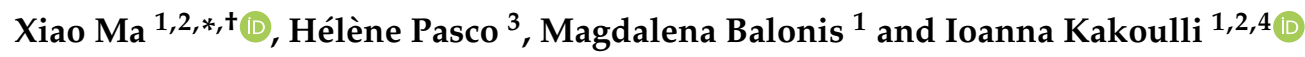 \\ 1 Department of Materials Science and Engineering, University of California at Los Angeles, 410 Westwood \\ Plaza, Los Angeles, CA 90095-1595, USA \\ 2 Molecular and Nano Archaeology Laboratory, Henry Samueli School of Engineering and Applied Science, \\ Engineering V-1230B, 410 Westwood Plaza, Los Angeles, CA 90095-1595, USA \\ 3 Sorbonne Université, Faculté des Sciences et Ingénierie, UFR 926, F-75005 Paris, France \\ 4 UCLA/Getty Conservation Program, A210 Fowler Building, University of California at Los Angeles, \\ Los Angeles, CA 90095-1510, USA \\ * Correspondence: xiaomapurdue@gmail.com \\ + Current address: Scientific Research Department, National Gallery of Art, 2000B South Club Drive, \\ Landover, MD 20785, USA.
}

Received: 19 May 2019; Accepted: 8 July 2019; Published: 11 July 2019

\begin{abstract}
This research investigates and evaluates the optical, physical, and chemical interactions between diammonium hydrogen phosphate (DAP) and seven pigments commonly encountered in archaeological and historic fresco and secco wall paintings and polychrome monuments. The pigments include cinnabar, French ochre, chalk, lapis lazuli, raw sienna, burnt umber, and red lead. The raw pigments were analyzed before and after the interaction with DAP, and the reaction products resulting from the contact of the pigments with the DAP solution were evaluated to obtain a comprehensive understanding of the effects of diammonium hydrogen phosphate on the color, morphology, and chemical composition of the pigments. The results indicated no significant change of the color or of the chemistry of cinnabar, French ochre, and lapis lazuli. Carbonate-containing pigments, such as chalk and calcium carbonate, were transformed into calcium phosphate, though without a significant change in color. Phase and strong color changes occurred only for the red lead pigment, associated with the transformation of red lead into hydroxypyromorphite. These data established the parameters and identified the risks of the direct application of DAP solutions on pigments. Further research will be undertaken to assess the potential use of DAP as a consolidant of wall paintings and other polychrome surfaces through testing on wall painting/polychromy mockups and on-site archaeological/historic painted surfaces.
\end{abstract}

Keywords: hydroxyapatite; diammonium hydrogen phosphate; pigment alteration; wall painting consolidation; cultural heritage

\section{Introduction}

Cultural heritage materials including wall paintings and other forms of polychromy and painted architectural surfaces were central to the culture of ancient people. These complex, heterogeneous, and multilayer systems are usually composed of the paint layer (a binary system of pigment(s) and a binding medium) and the substrate (a rock surface or plaster(s) layers) [1,2]. In ancient and historical times, two different techniques were predominantly employed for painting on walls: the fresco (from the Italian, meaning 'fresh') and the secco (from the Italian, meaning 'dry') techniques. In the fresco technique, a small number of pigment powders—compatible with fresco application—are mixed with 
water and applied on a freshly laid or moist calcium hydroxide/lime $\left(\mathrm{Ca}(\mathrm{OH})_{2}\right)$-rich plaster layer. Setting (hardening) of the lime plaster involves a chemical reaction between $\mathrm{Ca}(\mathrm{OH})_{2}$ and carbon dioxide $\left(\mathrm{CO}_{2}\right)$ present in the atmosphere to form a calcium carbonate lattice within which the pigments are 'fixed' and become an integral part of the wall. These chemical reactions help produce durable wall paintings. Owing to the high alkalinity of the lime and the exothermic reaction associated with the setting of the lime, only a small number of pigments are compatible with the fresco technique, and therefore ancient fresco paintings contain a limited palette of colors. The secco technique, on the other hand, involves no chemical reaction for the fixation of the pigments. In a secco application, the pigments are mixed with any film-forming binding medium such as egg, siccative oil, gum, and others [1] and applied on any type of finished plaster layer including gypsum, earth-based plasters, and lime plaster layers (fully carbonated).

As wall paintings constitute an integral part of the architectural ensemble where they are found, they are inevitably exposed to an open system of environmentally-linked events. As a result, the physical and chemical attributes of the system and individual constituent materials (i.e., plaster(s), pigment(s), binding media) can be impacted by fluctuations in the temperature, relative humidity, and presence of salts, microorganisms, and pollution in the surrounding environment. These conditions can compromise the stability of the system, resulting in the delamination of the plaster layers, staining, flaking, and losses of the paint and plaster layers, and powdering [1,3]. For archaeological wall paintings in particular, the risks for their preservation are even greater as the sudden change in the environmental conditions at the time of the excavation-mainly of the temperature, relative humidity, and light—can cause irreversible damage and degradation [1].

Over the course of the past decades, extensive studies have been carried out using a variety of consolidation treatments to improve the condition and re-establish the lost cohesion of decorated architectural surfaces and wall paintings [4-12]. These studies critically indicate that choosing a proper consolidating agent for these porous materials, especially those found in situ, is challenging. An appropriate consolidant for wall paintings needs to re-establish cohesion of the powdery layers at the surface and subsurface levels and provide mechanical strength and abrasion resistance, without causing any discernible color alteration [13].

Recent studies [14-25] have demonstrated a considerable potential for improving consolidation methods of degraded calcium-carbonate matrices of a technique consisting in bio-mimicking the growth of hydroxyapatite (HAP, with the formula $\mathrm{Ca}_{5}\left(\mathrm{PO}_{4}\right)_{3}(\mathrm{OH})$ but usually written as $\mathrm{Ca}_{10}\left(\mathrm{PO}_{4}\right)_{6}(\mathrm{OH})_{2}$ to denote that the crystal unit cell comprises two formula units), the main mineralogical component of teeth and bones $[15,26,27]$. HAP was proved to be effective in binding grain boundaries and improving the mechanical properties of limestone, such as tensile strength, ultrasonic pulse velocity, resistance to abrasion $[16,19,20]$.

$\mathrm{HAP}$ is formed in situ by activating reactions between $\mathrm{Ca}$ in calcium carbonate $\left(\mathrm{CaCO}_{3}\right)$-rich layers and ammonium phosphate precursors. The theoretical chemical pathway of HAP formation using diammonium hydrogen phosphate (DAP) as the precursor is presented below (Reaction 1) [28]. The resulting hydroxyapatite network is expected to improve the cohesion between loose particles at the surface and subsurface of a wall painting [21,29].

$$
10 \mathrm{CaCO}_{3}+6\left(\mathrm{NH}_{4}\right)_{2} \mathrm{HPO}_{4} \rightarrow \mathrm{Ca}_{10}\left(\mathrm{PO}_{4}\right)_{6}(\mathrm{OH})_{2}+10 \mathrm{CO}_{2} \uparrow+12 \mathrm{NH}_{3} \uparrow+8 \mathrm{H}_{2} \mathrm{O}
$$

Reaction 1. Theoretical pathway of the formation of hydroxyapatite (HAP) using diammonium hydrogen phosphate as a precursor.

The superior qualities of $\mathrm{HAP}$ as a consolidating agent for calcium carbonate matrices lie in the fact that it has a much lower solubility $\left(\mathrm{K}_{\mathrm{sp}}=1.6 \times 10^{-117}\right.$ at $\left.25^{\circ} \mathrm{C}[30]\right)$ than calcite $\left(\mathrm{K}_{\mathrm{sp}}=3.4 \times 10^{-9}\right.$ at $25^{\circ} \mathrm{C}$ [31]). The lattice parameters of hydroxyapatite and calcite are relatively close, respectively, $\mathrm{a}=$ $\mathrm{b}=9.43 \AA$ and $\mathrm{c}=6.88 \AA$ for HAP [32], and $\mathrm{a}=\mathrm{b}=9.96 \AA$ and $\mathrm{c}=17.07 \AA$ for calcite, considering 
two molecules per unit cell [33]. This indicates compatibility in the nucleation of the phosphate layer onto the surface of carbonate stones and strong bonding of the newly formed layer onto the substrate [21]. The other advantage is that hydroxyapatite is the least soluble and the most stable calcium phosphate phase in aqueous solutions at $\mathrm{pH}$ values higher than 4.2 [34,35]. Also, it has a dissolution rate about $4-5$ orders of magnitude lower than that of calcite: $R_{\text {diss, HAP }}=1 \times 10^{-14}$ moles $\cdot \mathrm{cm}^{-2} \cdot \mathrm{s}^{-1}$, and $\mathrm{R}_{\text {diss, calcite }}=2 \times 10^{-10}$ moles $\cdot \mathrm{cm}^{-2} \cdot \mathrm{s}^{-1}$ at $\mathrm{pH}=5.6 ; \mathrm{R}_{\text {diss, HAP }}=3.7 \times 10^{-14}$ moles $\cdot \mathrm{cm}^{-2} \cdot \mathrm{s}^{-1}$, and $\mathrm{R}_{\text {diss, calcite }}=5.4 \times 10^{-9}$ moles $\cdot \mathrm{cm}^{-2} \cdot \mathrm{s}^{-1}$ at $\mathrm{pH}=4[36,37]$. It is therefore more stable in a range of $\mathrm{pH}$ and it is expected to provide additional protection against acid dissolution. In addition, the precursor ammonium phosphate is non-toxic, and a good penetration depth could be obtained in the consolidation treatment [21].

However, despite successful results for the consolidation of decohesive plaster layers as substrates/surface layers of fresco wall paintings [21] and regardless of the fact that some other consolidants, such as a nano calcium hydroxide suspension, have been tested on fresco wall painting mock-ups [38], this DAP-based method has not yet been tested on archaeological wall paintings nor has any thorough assessment been performed on pigments. This research aims to fill this gap of knowledge. Following from our previous research on the application of DAP for the consolidation of fresco plaster layers, here, as a first step, we systematically investigate and evaluate in laboratory-controlled conditions the optical, physical, and chemical effects of the ammonium phosphate precursor of HAP on selected pigments (mainly those compatible with fresco application). The aim is to have a fundamental understanding of the effects (mainly on color change and phase transformations) of this inorganic 'consolidant' precursor on pigments, prior to any testing of the consolidating effect on the paint layer (both fresco and secco) in wall painting mockups and archaeological/historic wall paintings and other polychrome monuments. More specifically, this research investigates the interactions between DAP solutions and seven pigments commonly found in wall paintings and other polychrome surfaces and focuses on answering the following questions:

- Can DAP be considered as a potential precursor for a surface treatment of wall paintings (mainly fresco) and other monumental painted architectural surfaces?

- Is there any obvious color change of pigments after contact with DAP solutions?

- Are any chemical or morphological changes occurring?

- What are the possible mechanisms leading to color change and/or other forms of physical and chemical phase transformation?

\section{Materials and Methods}

\subsection{Materials}

A 1M DAP solution was prepared by adding the appropriate amount of DAP (Fisher Scientific, Hampton, NH, USA, purity: $99+\%$, used as received) to deionized (DI) water. To study the chemical reaction between the DAP solution and the pigments, seven commercial inorganic pigments purchased from Kremer Pigments Inc. were tested, including six pigments commonly used for fresco application, such as cinnabar (Kremer No.10620), lapis lazuli (Kremer No. 10562), white chalk (Kremer No. 58000), French ochre (Kremer No. 40090), burnt umber (Kremer No. 40710), raw sienna (Kremer No. 40400), and one pigment, red lead (Kremer No. 42500), frequently encountered in secco paintings.

\subsection{Characterization of Pigment-DAP Interaction}

For the experimental application, $10 \mathrm{~g}$ of each pigment were dispersed in $100 \mathrm{~mL}$ of $1 \mathrm{M}$ DAP solution or in $100 \mathrm{~mL}$ of DI water, which was used as a control sample, and the dispersions were subsequently sealed in a glass bottle. The bottles were kept in the dark to avoid any photochemical reaction. The room temperature (T) was maintained at $\sim 22^{\circ} \mathrm{C}$, and the relative humidity (RH) at $\sim 50 \%$. Using an Oakton EcoTestr ${ }^{\circledR} \mathrm{pH} 2$ Waterproof $\mathrm{pH}$ Tester (standard error: \pm 0.1 ), $\mathrm{pH}$ measurements were taken of the $1 \mathrm{M}$ DAP solution and of each pigment dispersion on day 0 , a few minutes after the pigments were dispersed in the DAP solution, and subsequently at regular intervals: every $24 \mathrm{~h}$ 
between day 1 and 7 and then on day 14,21, and 28. Monitoring of color/phase change of those pigments was carried out in the first 28 days. Red lead and chalk, however, showed phase and color change after two months of immersion in the DAP solution. For these two pigments, further monitoring will be required.

Prior to subjecting the samples to the measurements, all the powders were rinsed using DI water and left to dry overnight on filter paper. The powders were analyzed every $24 \mathrm{~h}$ between day 1 and 7 , and then on day 14,21 , and 28 , following the dispersion into $1 \mathrm{M} \mathrm{DAP} \mathrm{solution.} \mathrm{The} \mathrm{samples} \mathrm{listed} \mathrm{were}$ named using the abbreviation of the pigment name and the immersion time. For instance, CIN-raw stands for cinnabar pigment prior to the analysis, whereas CIN-d28 stands for cinnabar precipitate collected 28 days after dispersion in 1M DAP solution.

All powders were first examined using a Keyence VHX-1000 Digital Optical Microscope, using a magnification between $20 \times$ and $200 \times$.

XRD measurements on the pigment powders were performed using a Bruker D8 diffractometer with the following measurement parameters: $\mathrm{Cu}-\mathrm{K} \alpha$ radiation, $\lambda=1.5404 \AA$, voltage $40 \mathrm{kV}$, beam current $40 \mathrm{~mA}$, and a $2-80^{\circ} 2 \theta$ exploration range with a step size of $0.014^{\circ} 2 \theta$. The mineral phases were identified by using the ICDD database (International Center for Diffraction Data, Newtown Square, PA, USA).

TGA analysis was performed on selected pigment powders using a Perkin Elmer Pyris Diamond TG/DTA (Thermogravimetric/Differential Thermal Analyzer). The temperatures were scanned in the range between $40^{\circ} \mathrm{C}$ to $900{ }^{\circ} \mathrm{C}$, at the heating rate of $20^{\circ} \mathrm{C} / \mathrm{min}$, in a flowing Ar atmosphere.

Microstructural and elemental analyses of the powders were performed on a FEI Nova NanoSEM ${ }^{\mathrm{TM}}$ 230 scanning electron microscope (SEM) with field emission gun (FEG) and variable pressure (VP) capabilities, equipped with a Thermo Scientific ${ }^{\mathrm{TM}}$ NORAN $^{\mathrm{TM}}$ System $7 \mathrm{X}$-ray energy dispersive spectrometer (EDS). Gold (Au) coating to improve the electrical conductivity was applied using a Hummer ${ }^{\circledR} 6.2$ sputtering system (Anatech Ltd., Battle Creek, MI, USA). Secondary electron (SE) imaging was performed in vacuum using the Everhart-Thornley detector (ETD). The elemental composition of single spots and area elemental maps were acquired using EDS.

FTIR spectroscopy was performed on a JASCO FT/IR-420 Fourier-Transform Infrared Spectrometer using the $\mathrm{KBr}$ pellet method. Pigment powders were ground and dispersed in a $\mathrm{KBr}$ matrix at a concentration around $0.5 \mathrm{wt} \%$ and then pressed into a pellet. All spectra were collected at 64 scans with a spectral resolution of $4 \mathrm{~cm}^{-1}$, from 4000 to $400 \mathrm{~cm}^{-1}$. The spectra were matched against the spectral database of the Infrared and Raman Users Group (IRUG, Philadelphia, PA, USA) and published literature data.

FORS (Fiber Optic Reflectance Spectroscopy) was conducted using an Ocean Optics USB 2000+ fiber optical spectrophotometer and the FieldSpec $3^{\circledR}$ Spectroradiometer (Analytical Spectral Devices Inc., Boulder, CO, USA). The spectro-colorimetric measurements allowed for the quantification of incident and reflected radiation intensities, which roughly equal human color perception. During the measurement, a white diffuse reference standard was measured every $30 \mathrm{~min}$. Color values were recorded in the $\mathrm{L}^{*} \mathrm{a}^{*} \mathrm{~b}^{*}$ color space defined in 1976 by CIE (Commission Internationale de l'Eclairage, Vienna, Austria) [39]. Changes in color/color difference $\left(\Delta \mathrm{E}^{*}\right)$ were calculated with the following formula (Equation (1)) as recommended by the CIE:

$$
\Delta \mathrm{E}^{*}=\left[\left(\Delta \mathrm{L}^{*}\right)^{2}+\left(\Delta \mathrm{a}^{*}\right)^{2}+\left(\Delta \mathrm{b}^{*}\right)^{2}\right]^{1 / 2}
$$

where $\Delta \mathrm{L}^{*}, \Delta \mathrm{a}^{*}$, and $\Delta \mathrm{b}^{*}$ are the differences in $\mathrm{L}^{*}, \mathrm{a}^{*}$, and $\mathrm{b}^{*}$ values before and after immersion in the DAP solution. $\Delta \mathrm{L}^{*}$ describes the change in luminance, $\Delta \mathrm{a}^{*}$ the change in red/green components, and $\Delta \mathrm{b}^{*}$ the change in yellow/blue components. While generally $\Delta \mathrm{E}^{*} \leq 2$ is widely acceptable as the value detectable by the human eye [40], a color difference of $\Delta \mathrm{E}^{*} \leq 5$ has been established as the threshold in the field of cultural heritage to evaluate color change after a conservation intervention such as consolidation treatment [16,41-48]. 


\section{Results and Discussion}

After 28 days of immersion of the pigments in the DAP solution, the pigments were assessed on the basis of phase transformations and color change. Three main groups were revealed: (1) pigments that showed no chemical and/or optical interaction (no phase or significant color change) with DAP (i.e., cinnabar, French ochre, and lapis lazuli); (2) pigments that showed phase transformation without significant color change (i.e., chalk, raw sienna, and burnt umber); and (3) pigment with strong phase and color change (i.e., red lead).

\subsection{Cinnabar, French Ochre, Lapis Lazuli}

The calculated $\Delta \mathrm{E}^{*}$ values for cinnabar, French Ochre, and lapis lazuli pigment particles before and after the 28 days of immersion in DAP were determined to be 3.5, 3.4, and 4.2 , respectively (Table 1). Though these values are above the threshold of color change detected by the human eye [40], they are still below the established value $\left(\Delta \mathrm{E}^{*} \leq 5\right)$ accepted for cultural heritage consolidation treatments [16,41-48].

\subsubsection{Cinnabar}

Cinnabar has a deep red color with angular particles of various sizes up to $100 \mu \mathrm{m}$ (Figure 1a-d). Its identification was based on XRD analysis (Figure 1e) and FORS (Figure 1f) which showed consistently the characteristic sigmoid-shaped spectrum with an inflection point (maximum at its first derivative, Figure $1 \mathrm{~g}$ ) at $\sim 614 \mathrm{~nm}$ corresponding to the bandgap of cinnabar [49]. No obvious change in shape or size of the cinnabar pigment particles (inferred by SEM-EDS analysis) was observed (Figure 1a-d).

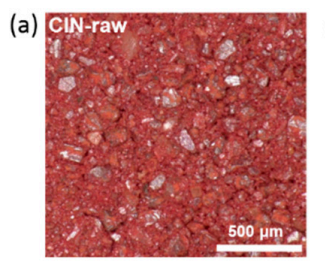

(c)
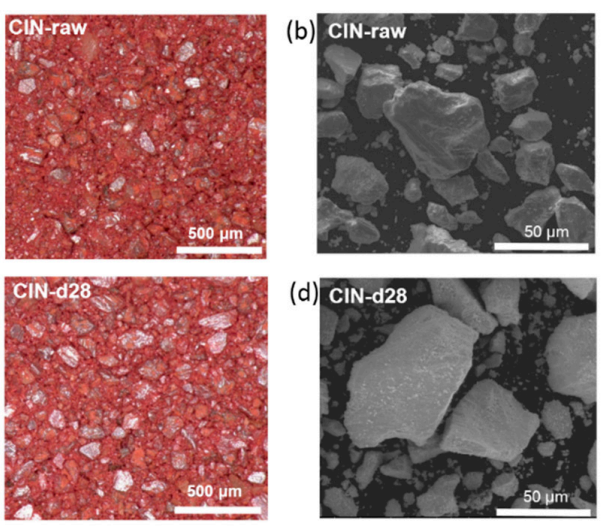

(e) Cinnabar XRD Pattern
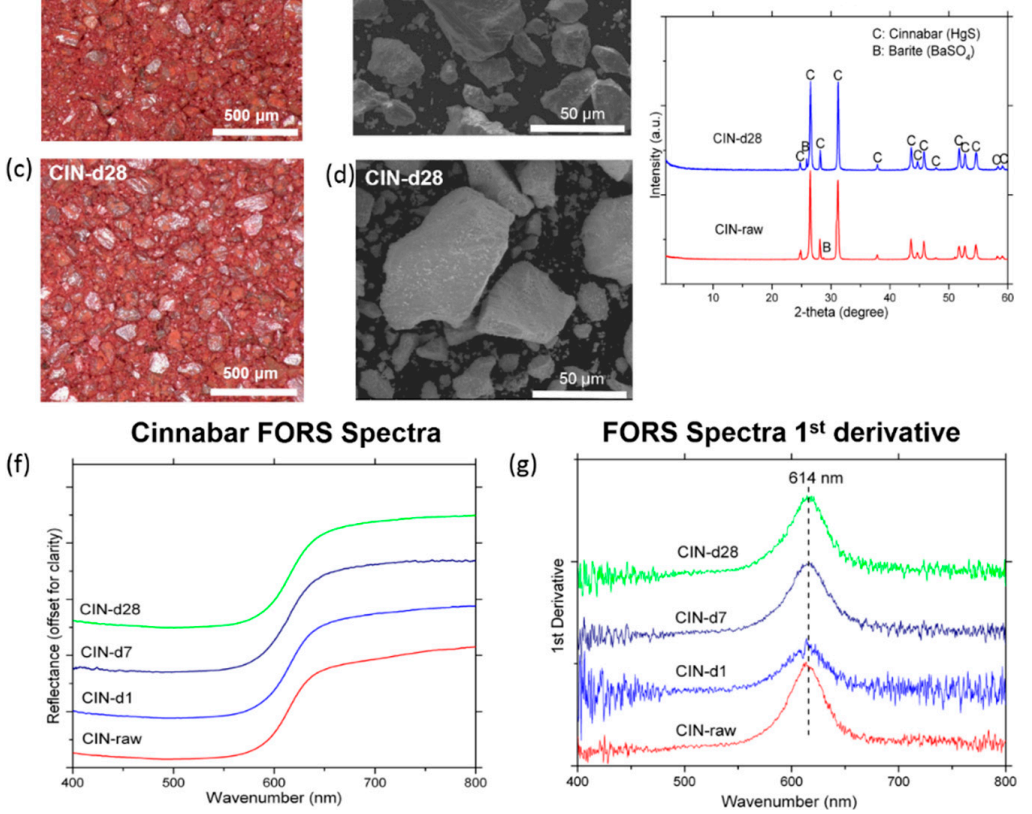

Figure 1. (a) Photomicrograph of the cinnabar (CIN)-raw sample; (b) secondary electron (SE) micrographs of the CIN-raw sample; (c) DM (Digital Micrograph) photomicrograph of the sample CIN-d28; (d) SE micrographs of the sample CIN-d28; (e) XRD pattern of CIN-raw and CIN-d28 ; (f) FORS spectra of cinnabar: CIN-raw, CIN-d1, CIN-d7, CIN-d28; (g) first derivative of the FORS spectra in (f). The intensity values of each XRD pattern, FORS spectra, and its first derivative plots were normalized and offset for comparison purposes. 


\subsubsection{French Ochre}

Based on the XRD, FTIR, and FORS analysis (Figure 2), no detectable phase transformations were observed in the pigment particles subjected to the immersion in DAP solution (FRE-d28) as compared to the untreated powders (FRE-raw).
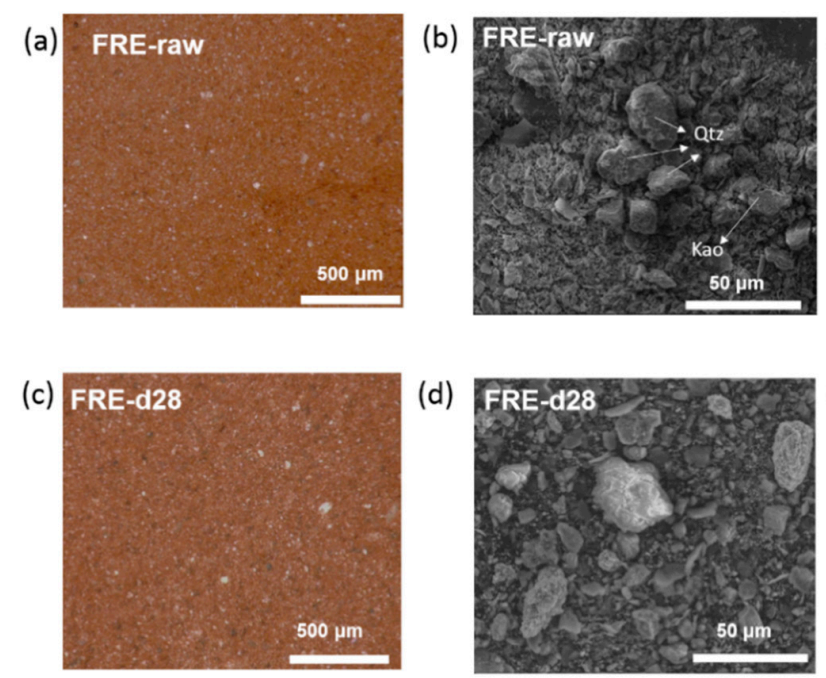

(d)

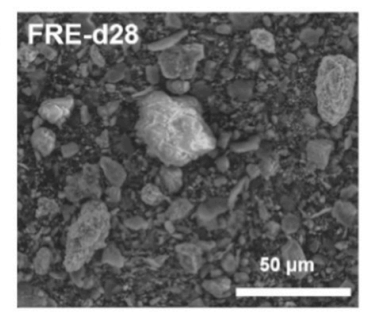

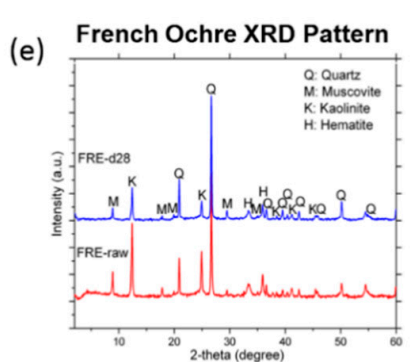

(f)

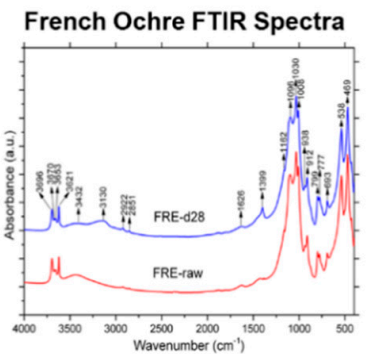

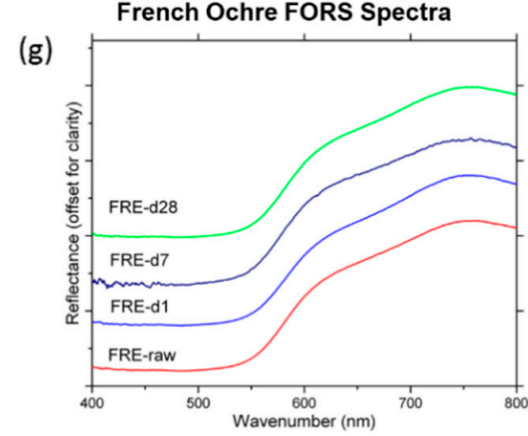

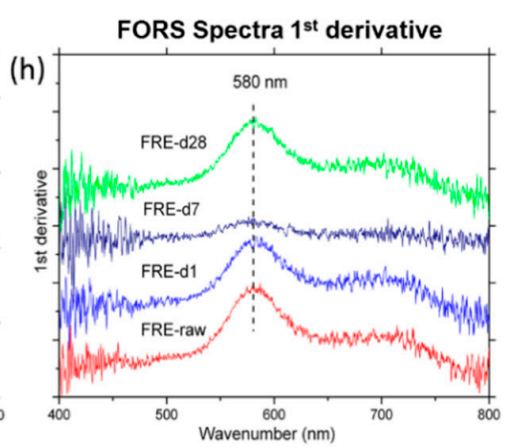

Figure 2. (a) Photomicrograph of the French ochre (FRE)-raw sample; (b) micrographs of the FRE-raw. Qtz stands for quartz and Kao stands for kaolinite; (c) photomicrograph of the sample FRE-d28; (d) micrographs of the FRE-d28; (e) XRD pattern of the samples FRE-raw and FRE-d28; (f) FTIR spectra of the FRE-raw, FRE-d1, and FRE-d28 samples; (g) FORS spectra of the French ochre samples FRE-raw, FRE-d1, FRE-d7, FRE-d28; (h) first derivative of the FORS spectra in (g). The intensity values of each XRD pattern, FORS spectra, and its first derivative plots were normalized and offset for comparison purposes.

XRD analysis (Figure 2e) revealed the presence of quartz, muscovite, kaolinite, and hematite. FTIR spectroscopy (Figure 2f) further corroborated the results. Kaolinite $\left(\mathrm{Al}_{2} \mathrm{Si}_{2} \mathrm{O}_{5}(\mathrm{OH})_{4}\right)$ disclosed vibrational bands at 3696, 3670, $3653 \mathrm{~cm}^{-1}$ (surface hydroxyl groups stretching vibration), $3621 \mathrm{~cm}^{-1}$ (inner hydroxyl groups stretching vibration), $1030 \mathrm{~cm}^{-1}$ (Si-O-Si stretching vibration), $1008 \mathrm{~cm}^{-1}$ (Si-O-Al stretching vibration), 938 and $912 \mathrm{~cm}^{-1}$ (Al-OH deformation vibration), $693 \mathrm{~cm}^{-1}$ (Si-O-Si symmetrical bending vibration), $538 \mathrm{~cm}^{-1}$ (Si-O-Al stretching vibration), and $469 \mathrm{~cm}^{-1}$ (Si-O-Si asymmetrical bending vibration). Quartz $\left(\mathrm{SiO}_{2}\right)$ exhibited vibrational bands at $1162 \mathrm{~cm}^{-1}(\mathrm{Si}-\mathrm{O}-\mathrm{Si}$ rocking vibration), $1096 \mathrm{~cm}^{-1}$ (Si-O-Si asymmetrical stretching vibration), doublets at 777 and 799 $\mathrm{cm}^{-1}$ (Si-O-Si symmetrical stretching vibration) and at $693 \mathrm{~cm}^{-1}$ and $469 \mathrm{~cm}^{-1}$ (Si-O-Si symmetrical and asymmetrical bending vibration, overlapping with kaolinite). It should be noted that the $\mathrm{Fe}-\mathrm{O}$ vibration of hematite which yields vibrational bands at $538 \mathrm{~cm}^{-1}$ and $469 \mathrm{~cm}^{-1}$, were overlapping with the $\mathrm{Si}-\mathrm{O}-\mathrm{Al}$ stretching vibration of kaolinite and the $\mathrm{Si}-\mathrm{O}-\mathrm{Si}$ bending vibration of kaolinite/quartz, 
respectively [50-56]. The bands at $3432 \mathrm{~cm}^{-1}$ and $1626 \mathrm{~cm}^{-1}$ corresponded to the $\mathrm{O}-\mathrm{H}$ stretching and $\mathrm{O}-\mathrm{H}$ bending of surface-absorbed water. The bands at $3130 \mathrm{~cm}^{-1}$ and $1399 \mathrm{~cm}^{-1}$ were present probably due to the $v_{3}$ stretching vibration and the $v_{4}$ bending vibration of surface-adsorbed $\mathrm{NH}_{4}{ }^{+}$[57-59].

FORS showed the characteristic inflection point (maximum at its first derivative (Figure $2 \mathrm{~g}$ ) of hematite at around $580 \mathrm{~nm}$ (Figure $2 \mathrm{~h}$ ). The broad absorption at $\sim 875 \mathrm{~nm}$ also characteristic of hematite, could not be seen in this spectrum (cut off at $800 \mathrm{~nm}$ ). These were attributed to ligand-to-metal charge transfer transitions in hematite [60].

\subsubsection{Lapis Lazuli}

The lapis lazuli pigment powder analyzed for this research (sample LAP-raw) was found to contain various minerals including lazurite, wollastonite, cancrinite, and feldspars (Figure 3), with particle sizes ranging from 2 to $50 \mu \mathrm{m}$.

(a)

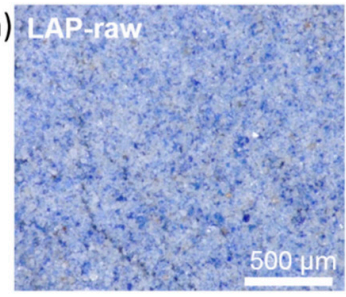

(c)
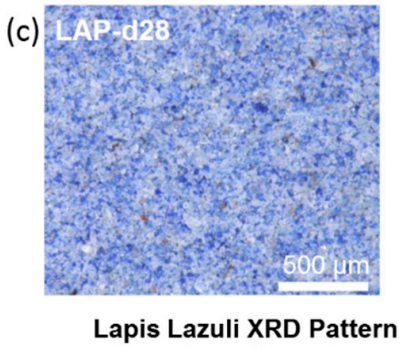

(e)

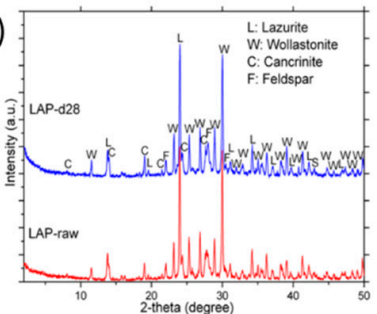

(b) LAP-raw

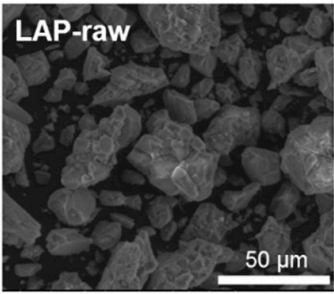

(d)

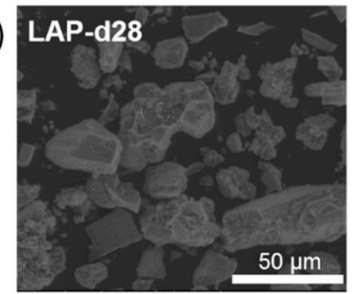

(f)
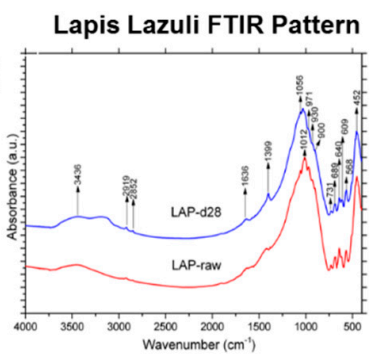

(g)

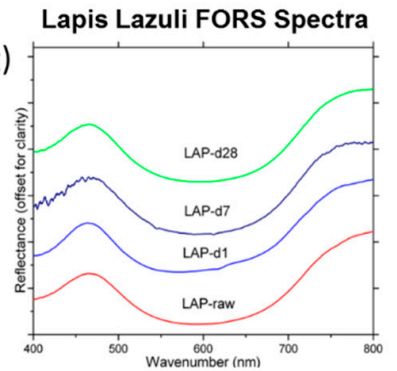

Figure 3. (a-b) Micrographs of the lapis lazuli pigment (LAP)-raw sample; (c-d) micrographs of the sample LAP-d28; (e) XRD pattern of the samples LAP-raw, LAP-d28; (f) FTIR spectra of the LAP-raw and LAP-d28 samples; (g) FORS spectra of the samples LAP-raw, LAP-d1, LAP-d7, LAP-d28. The intensity values of each XRD pattern and FORS spectra were normalized and offset for comparison purposes.

XRD (Figure 3e) and FTIR analysis (Figure 3f) showed no detectable phase changes resulting from the immersion in the DAP solution. The FTIR spectra showed bands in the $1100-900 \mathrm{~cm}^{-1}$ region that could be assigned to overlapping of $\mathrm{Al}, \mathrm{Si}-\mathrm{O}_{4}$ tetrahedra asymmetric stretching vibration of lazurite 
and $\mathrm{O}-\mathrm{Si}-\mathrm{O}$ asymmetric stretching vibration of wollastonite, as well as bands in the $700-600 \mathrm{~cm}^{-1}$ region, which could be linked to an overlapping of $\mathrm{Al}, \mathrm{Si}-\mathrm{O}_{4}$ tetrahedra symmetric stretching vibration of lazurite and $\mathrm{O}-\mathrm{Si}-\mathrm{O}$ symmetric stretching vibration of wollastonite [61]. The band at $568 \mathrm{~cm}^{-1}$ and the band at $452 \mathrm{~cm}^{-1}$ represent the terminal ${ }^{-} \mathrm{O}-\mathrm{Si}-\mathrm{O}^{-}$bonds bending vibration and $\mathrm{Si}-\mathrm{O}-\mathrm{Si}$ bending vibration, respectively [62-64].

The visible spectrum of the lapis lazuli was dominated by an absorption band around $600 \mathrm{~nm}$, corresponding to the electronic transitions for $\mathrm{S}_{3}{ }^{-}$(see Figure $3 \mathrm{~g}$ ).

\subsection{Chalk, Sienna, Burnt Umber}

The calculated $\Delta \mathrm{E}^{*}$ values for the chalk, raw sienna, and burnt umber pigment particles before and after 28 days of immersion in DAP were 4.9, 2.6, and 1.7, respectively (Table 1 ). Though the value of chalk was above the threshold of color change detected by the human eye [40], it was lower than the established value $\left(\Delta \mathrm{E}^{*} \leq 5\right)$ accepted for consolidation applications in cultural heritage [16,41-48]. The color change of burnt umber pigment remained below the detection limit of human eye.

\subsubsection{Chalk}

The pigment (CHA-raw) used for this research was a fine powder consisting of natural white calcium carbonate $\left(\mathrm{CaCO}_{3}\right)$ (Figure $\left.4 \mathrm{a}-\mathrm{c}\right)$ and was prepared from pure microcrystalline chalk with particle sizes less than $5 \mu \mathrm{m}$. After 28 days of immersion in $1 \mathrm{M}$ DAP solution, the chalk $\left(\mathrm{CaCO}_{3}\right)$ particles showed evident transformation into HAP $\left(\mathrm{Ca}_{10}\left(\mathrm{PO}_{4}\right)_{6}(\mathrm{OH})_{2}\right)$ and octacalcium phosphate $\left(\mathrm{OCP}, \mathrm{Ca}_{8} \mathrm{H}_{2}\left(\mathrm{PO}_{4}\right)_{6} \cdot 5 \mathrm{H}_{2} \mathrm{O}\right)$. The habit of the original calcium carbonate crystals had changed into "plate-like" crystals (Figure 4d-f). EDS mapping of the sample CHA-d28 showed that the major phases detected consisted of $\mathrm{Ca}, \mathrm{O}$, and $\mathrm{P}$ elements. This transformation continued even after a period of two months with more calcium carbonate crystals been transformed into calcium phosphate.
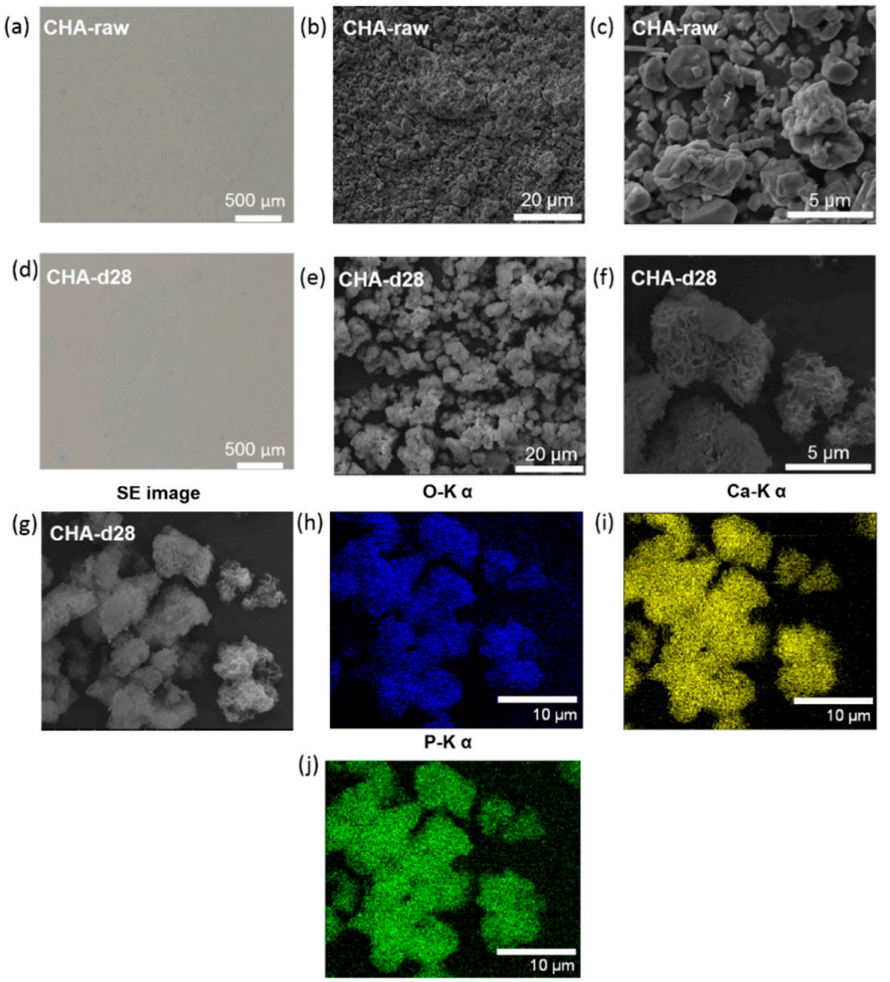

Figure 4. (a) Photomicrograph of the chalk (CHA)-raw sample; (b-c) micrographs of the CHA-raw sample; (d) photomicrograph of the sample CHA-d28; (e-f) micrographs of the CHA-d28 sample; $(\mathbf{g}-\mathbf{j})$ SE image and elemental mapping of the sample CHA-d28.

XRD analysis (Figure 5a) showed that the raw chalk pigment solely consisted of calcium carbonate (or calcite), while after 1 day and 28 days of immersion in DAP, some unreacted calcite, hydroxyapatite, 
and OCP were found to coexist. The consumption of calcite was not complete. FTIR analysis (Figure 5b) further confirmed the XRD results [65]. $\mathrm{CaCO}_{3}$ yielded bands at $712 \mathrm{~cm}^{-1}\left(v_{4}\right.$ in-plane bending vibration of $\left.\mathrm{CO}_{3}{ }^{2-}\right), 873 \mathrm{~cm}^{-1}\left(v_{2}\right.$ out-of-plane bending vibration of $\left.\mathrm{CO}_{3}{ }^{2-}\right), 1420 \mathrm{~cm}^{-1}\left(v_{3}\right.$ asymmetric stretching vibration of $\left.\mathrm{CO}_{3}{ }^{2-}\right)$, and combination bands at $2513 \mathrm{~cm}^{-1}$ and $1798 \mathrm{~cm}^{-1}$. In the sample CHA-d28, bands appeared at $468 \mathrm{~cm}^{-1}$ ( $v_{2}$ bending mode of $\mathrm{O}-\mathrm{P}-\mathrm{O}$ bond), $562 \mathrm{~cm}^{-1}$ ( $v_{4}$ bending mode of O-P-O bond), $601 \mathrm{~cm}^{-1}$ ( $v_{4}$ bending mode of $\mathrm{O}-\mathrm{P}-\mathrm{O}$ bond), $957 \mathrm{~cm}^{-1}$ ( $v_{1}$ symmetric stretching mode of $\mathrm{P}-\mathrm{O}$ bond), and $1033 \mathrm{~cm}^{-1}\left(v_{3}\right.$ asymmetric stretching mode of $\left.\mathrm{P}-\mathrm{O}\right)$. These are the vibration modes associated with the phosphate group present in HAP and OCP. [66]. The fraction of unreacted calcite was further estimated through TGA analysis, with a weight loss recorded between 600 and $860{ }^{\circ} \mathrm{C}$ linked to the decomposition of calcite. Weight losses of $43.2 \mathrm{wt} \%, 16.9 \mathrm{wt} \%$, and $11.55 \mathrm{wt} \%$ were observed for the samples CHA-raw, CHA-d1, and CHA-d28, respectively (Figure 5c-e). This roughly corresponded to calcite fractions of $98.2 \mathrm{wt} \%, 38.4 \mathrm{wt} \%$, and $26.25 \mathrm{wt} \%$, respectively. Most of the calcite was consumed on the first day of reaction with DAP.
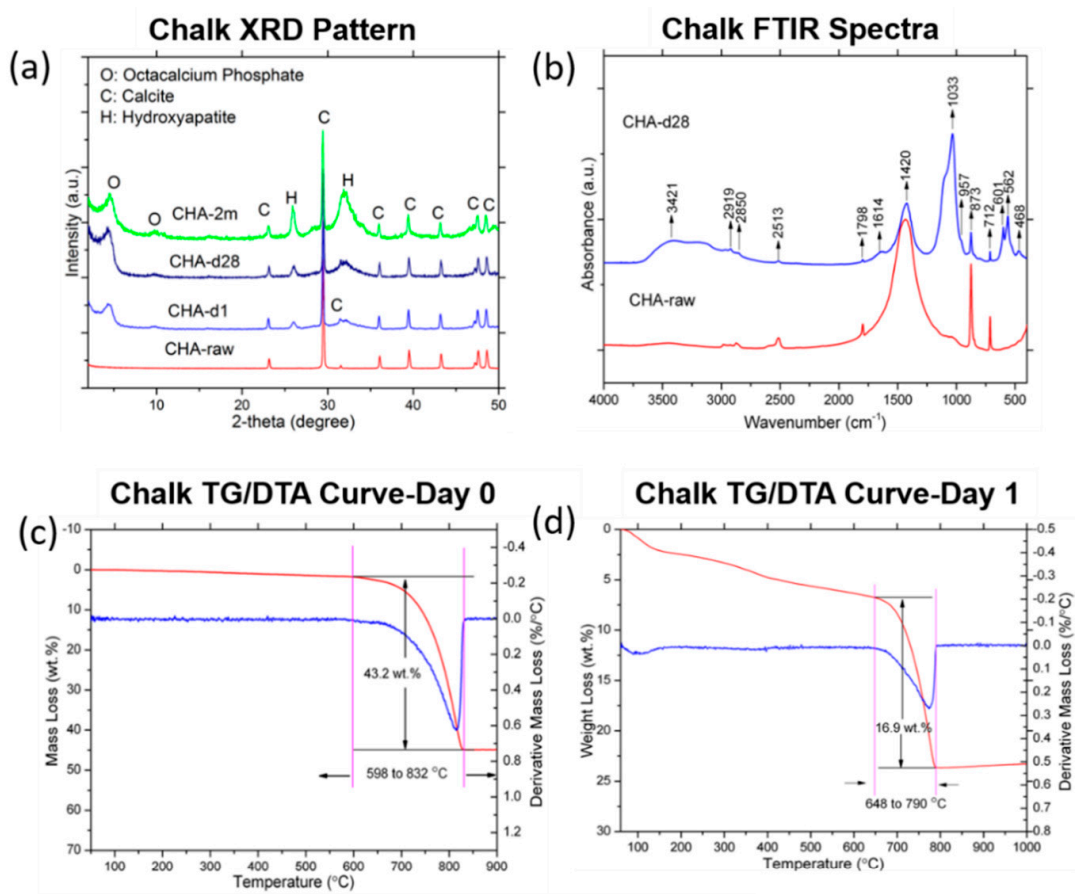

(e)
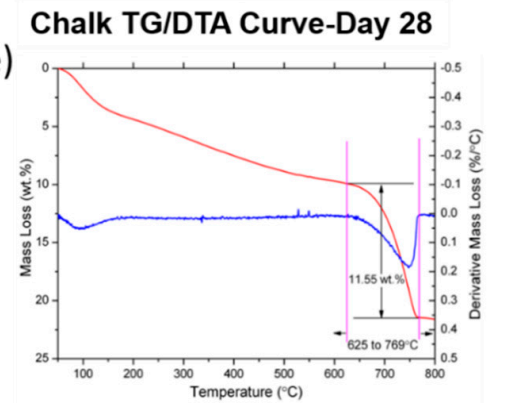

Figure 5. (a) XRD pattern of the samples CHA-raw, CHA-d1, CHA-d28, and CHA-2m; (b) FTIR spectra of the CHA-raw, CHA-d1, and CHA-d28 samples; (c-e) TGA of the sample CHA-raw, CHA-d1, and CHA-d28. The intensity of each XRD pattern was normalized and offset for comparison purposes.

OCP is commonly found to be present as an intermediate phase in the conversion process from amorphous calcium phosphates (ACP) to HAP (hydroxyapatite) [67]. This transition could explain the co-existence of HAP and OCP within the mixtures. While the formation of these phases and the kinetics of transformation largely depend on the reaction conditions such as $\mathrm{pH}$ and presence of foreign ions, 
ultimately-i.e., at thermodynamic equilibrium —-they are all expected to transform to HAP, which is thermodynamically the most stable phase $[67,68]$.

\subsubsection{Raw Sienna}

Microscopic examination of the sample SIE-raw (Figure 6a-b) showed that the pigment consists of different particles sizes ranging from sub-micron to $50 \mu \mathrm{m}$. XRD analysis of the SIE-raw and SIE- $\mathrm{d} 28$ (Figure 6e) samples indicated that raw sienna consisted of goethite $(\alpha-\mathrm{FeOOH})$, gypsum $\left(\mathrm{CaSO}_{4} \bullet 2 \mathrm{H}_{2} \mathrm{O}\right)$, calcite, quartz, and montmorillonite/clay. In the sample SIE-d1, gypsum was absent from the XRD pattern, whereas calcite could still be detected. This was due to the dissolution of gypsum into the DAP solution, while the transformation of calcite into HAP and/or OCP was not complete. For SIE-d28, however, the calcite peaks were absent, indicating that the amount of remaining calcite was probably below the detection limit ( 2-3 wt \%).
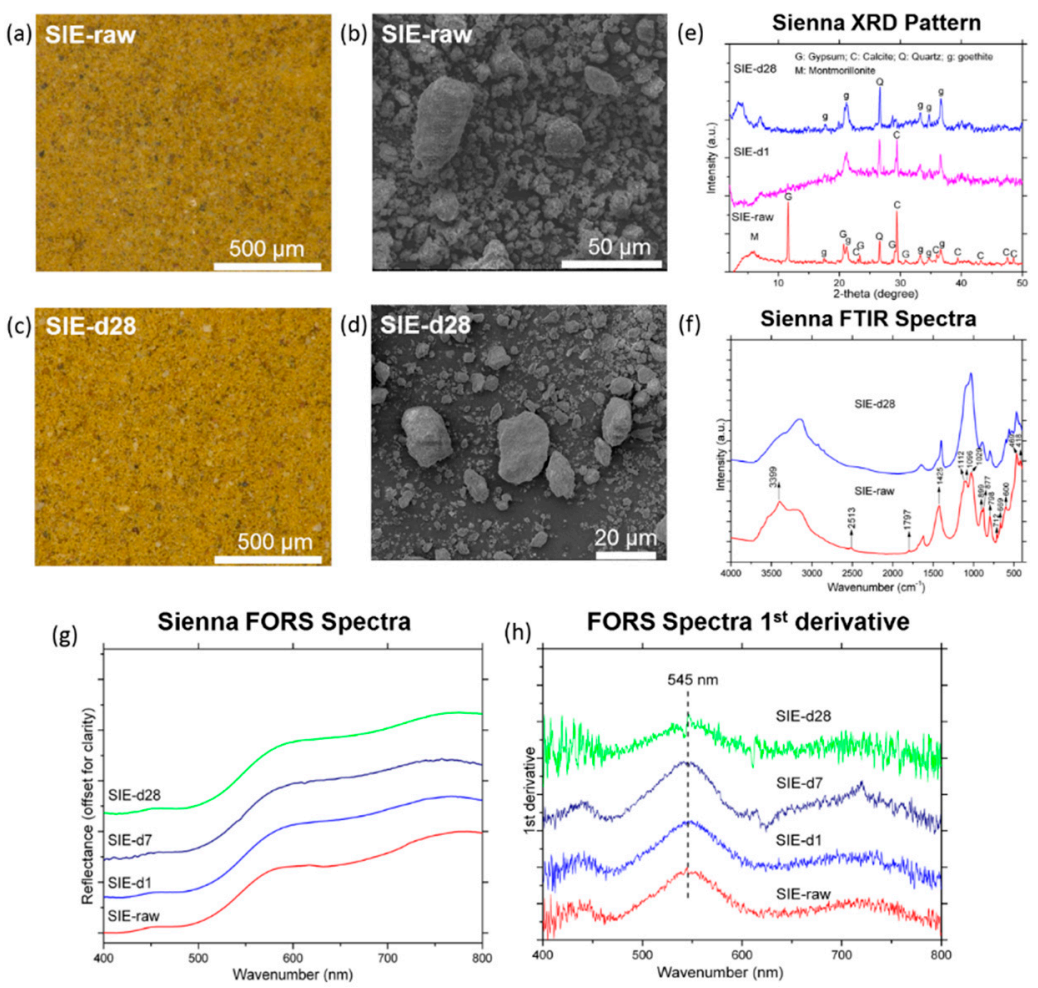

Figure 6. (a-b) Micrographs of the raw sienna pigment (SIE)-raw sample; (c-d) micrographs of the sample SIE-d28; (e) XRD pattern of the sample SIE-raw, SIE-d1, SIE-d28; (f) FTIR spectra of the SIE-raw and SIE-d28 samples; (g) FORS spectra of the samples SIE-raw, SIE-d1, SIE-d7, SIE-d28; (h) first derivative of the FORS spectra in $(\mathbf{g})$. The intensity values of each XRD pattern, FORS spectra, and its first derivative plots were normalized and offset for comparison purposes.

After 28 days of immersion in DAP solution, newly formed phosphate-bearing phases were identified through the FTIR (Figure 6f) and SEM-EDS techniques. In the spectra of SIE-raw, gypsum yielded bands at 3541 and $3399 \mathrm{~cm}^{-1}\left(v_{3}\right.$ asymmetric stretching vibration and $v_{1}$ symmetric stretching vibration of water molecule, respectively), 1685 and $1621 \mathrm{~cm}^{-1}$ (O-H bending vibration), $1112 \mathrm{~cm}^{-1}$ ( $v_{3}$ asymmetric stretching vibration of $\mathrm{SO}_{4}{ }^{2-}$ tetrahedron), $669 \mathrm{~cm}^{-1}\left(v_{4}\right.$ asymmetric bending vibration of $\mathrm{SO}_{4}{ }^{2-}$ tetrahedron), and $600 \mathrm{~cm}^{-1}\left(v_{4}\right.$ asymmetric bending vibration of $\mathrm{SO}_{4}{ }^{2-}$ tetrahedron). Quartz displayed characteristic bands at $1096 \mathrm{~cm}^{-1}$ (Si-O-Si asymmetrical stretching vibration), $798 \mathrm{~cm}^{-1}$ ( $\mathrm{Si}-\mathrm{O}-\mathrm{Si}$ symmetrical stretching vibration), and $469 \mathrm{~cm}^{-1}$ ( $\mathrm{Si}-\mathrm{O}-\mathrm{Si}$ asymmetrical bending vibration), while silicate clay had bands at $3621 \mathrm{~cm}^{-1}$ (O-H stretching vibration of structural hydroxyl group) and $1029 \mathrm{~cm}^{-1}$ (Si-O-Si asymmetrical stretching vibration) and shared (with quartz) bands at $798 \mathrm{~cm}^{-1}$ 
and $469 \mathrm{~cm}^{-1} . \mathrm{CaCO}_{3}$ produced bands at $712 \mathrm{~cm}^{-1}, 877 \mathrm{~cm}^{-1}, 1425 \mathrm{~cm}^{-1}, 1797 \mathrm{~cm}^{-1}$, and $2513 \mathrm{~cm}^{-1}$. Goethite gave a broad band centered at $3141 \mathrm{~cm}^{-1}$ (broad, $v_{2}$ stretching vibration of $\mathrm{O}-\mathrm{H}$ ) and bands at $899 \mathrm{~cm}^{-1}$ ( $8 \mathrm{O}-\mathrm{H}$ bending vibration) and $798 \mathrm{~cm}^{-1}(\gamma \mathrm{O}-\mathrm{H}$ bending vibration, overlapping with quartz and silicate clay) [69-76]. After 28 days of reaction with DAP, in the FTIR spectrum of SIE-d28, the calcite and gypsum bands disappeared with the appearance of the bands at $468 \mathrm{~cm}^{-1}, 562 \mathrm{~cm}^{-1}$, $601 \mathrm{~cm}^{-1}$, and $1034 \mathrm{~cm}^{-1}$, corresponding to the vibration mode of the newly formed phosphate group. The bands of goethite, quartz, and silicate clay remained unchanged. The appearance of the phosphate group and the disappearance of gypsum and calcite in the FTIR spectrum further indicated that calcite and gypsum were converted into calcium phosphates.

Reflectance spectra of the yellow iron hydroxide pigment (goethite) showed the characteristic inflection point (maximum at its first derivative, Figure $6 \mathrm{~g}$ ) at around $545 \mathrm{~nm}$ and absorptions at 640 and $\sim 900 \mathrm{~nm}$ (the latter was not visible in the spectrum) (Figure 6h).

\subsubsection{Burnt Umber}

The burnt umber pigment powder analyzed for this research (sample BUR-raw) contained hematite and manganese oxide (inferred by EDS point analysis) and minor phases of calcite and quartz (Figure 7). It exhibited particle sizes ranging from sub-micron to $20 \mu \mathrm{m}$ (Figure 7b).
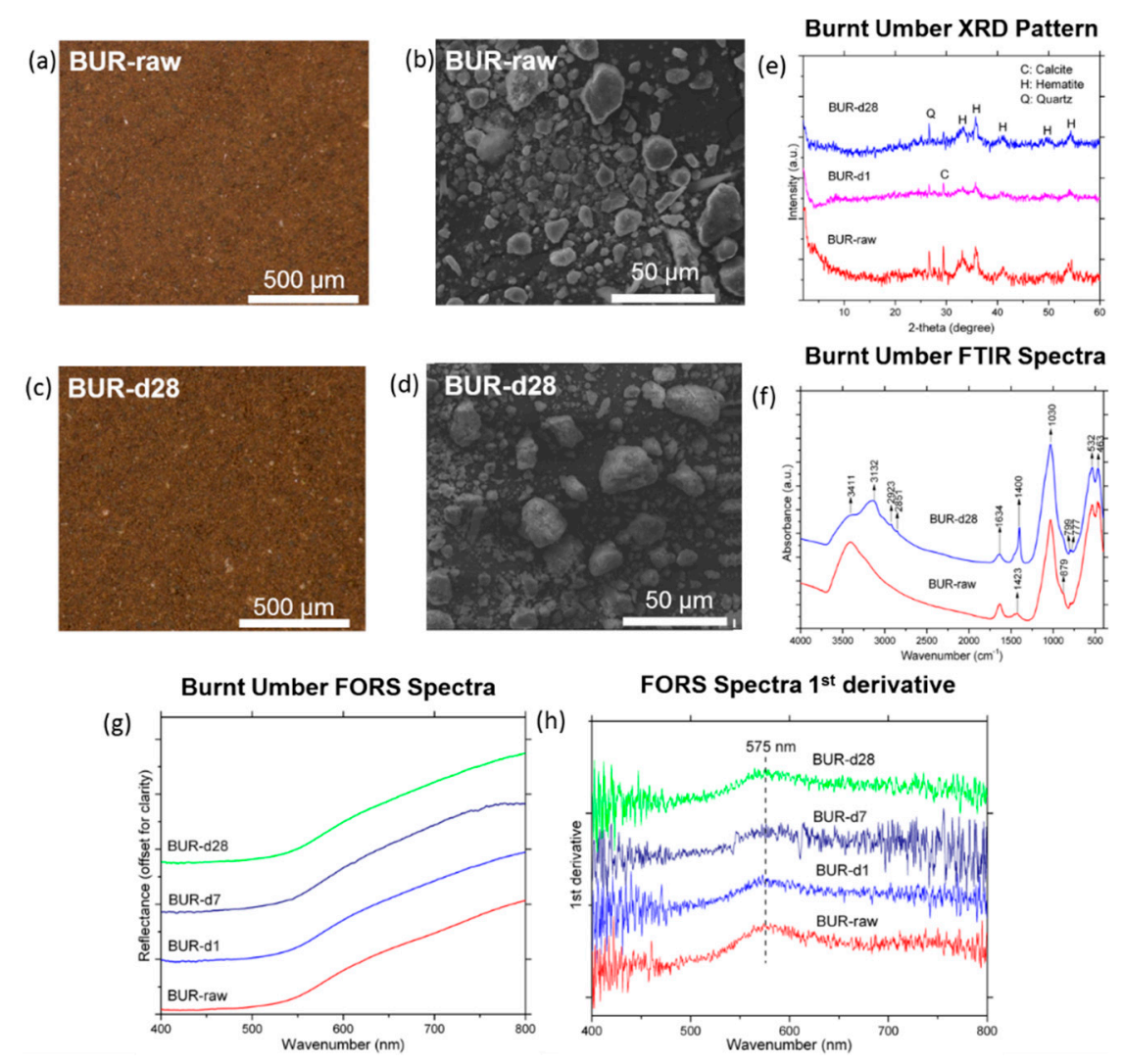

Figure 7. (a-b) Micrographs of the burnt umber pigment (BUR)-raw sample; (c-d) micrographs of the sample BUR-d28; (e) XRD pattern of the sample BUR-raw, BUR-d1, BUR-d28; (f) FTIR spectra of the BUR-raw and BUR-d28 samples; (g) FORS spectra of the samples BUR-raw, BUR-d1, BUR-d7, BUR-d28; (h) first derivative of the FORS spectra in (g). The intensity values of each XRD pattern, FORS spectra, and its first derivative plots were normalized and offset for comparison purposes.

After 28 days of immersion in DAP solution, the formation of calcium phosphates was first estimated from the microstructural changes revealed by SEM-EDS analysis. XRD analysis (Figure 7e) of the sample BUR-raw showed that the raw burnt umber pigment consisted of hematite, quartz, and calcite; the latter was no longer detectable after 28 days in DAP solution (sample BUR-d28). FTIR 
analysis (Figure 7f) showed bands at 1423 and $879 \mathrm{~cm}^{-1}$, corresponding to the vibration of $\mathrm{CaCO}_{3}$, and bands at $1030,778,797$, and $463 \mathrm{~cm}^{-1}$ corresponding to the vibration of the silicate (possibly silicate clay and $\mathrm{SiO}_{2}$ ) group. The bands at 532 and $463 \mathrm{~cm}^{-1}$ were indicative of the $\mathrm{Fe}-\mathrm{O}$ vibration produced by hematite. After 28 days, no calcite could be detected by FTIR.

The FORS spectra of burned umber (Figure $7 \mathrm{~g}$ ) showed the same features as those collected for French ochre (Figure $7 \mathrm{~g}-\mathrm{h}$ ), since the main component of both pigments is hematite.

\subsection{Red Lead}

The red lead pigment powder analyzed in this study was found to be pure, consisting of minium $\left(\mathrm{Pb}_{3} \mathrm{O}_{4}\right)$ with small and irregular particles (Figure 8a-b) ranging in size from $2 \mu \mathrm{m}$ to $20 \mu \mathrm{m}$.
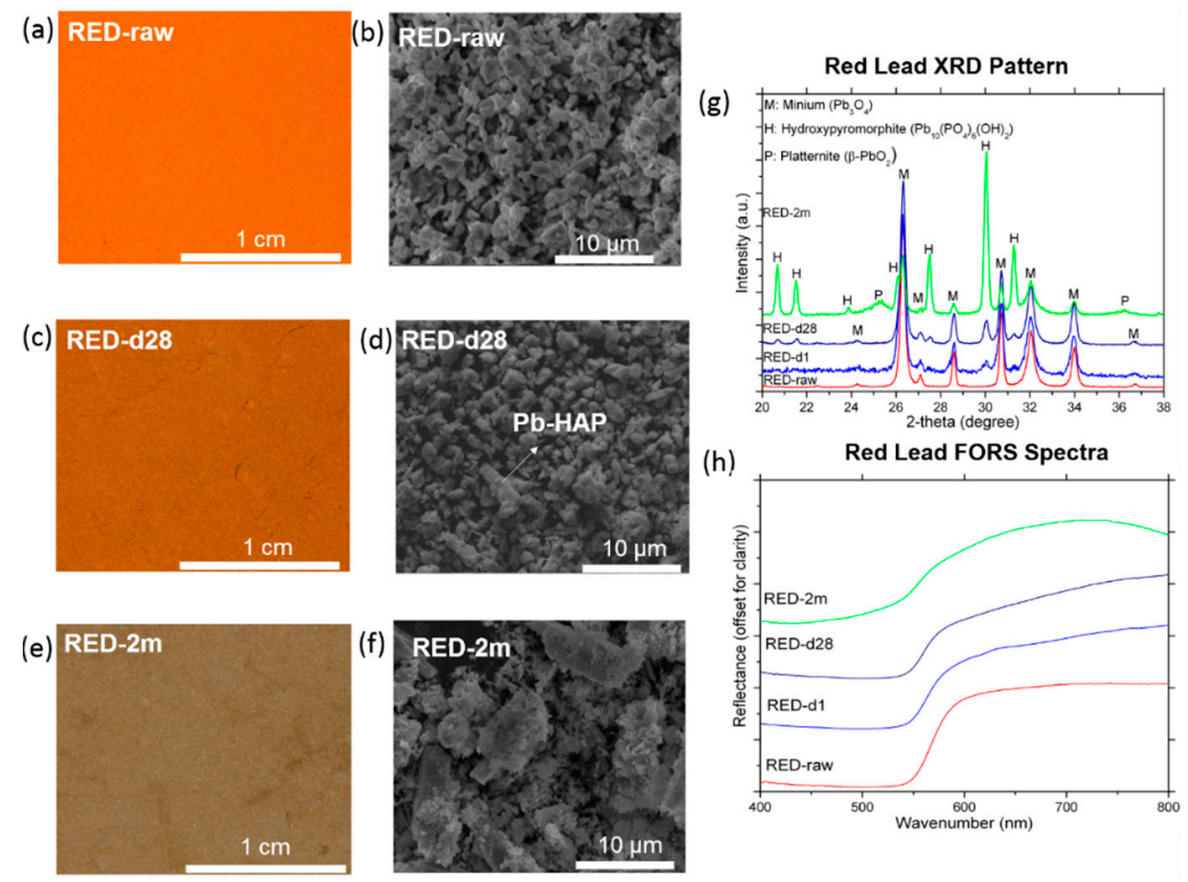

Figure 8. (a) Photomicrograph of the red lead (RED)-raw sample; (b) micrographs of the RED-raw; (c) photomicrograph of the sample RED-d28; (d) micrographs of the sample RED-d28, the elongated particle was identified as lead hydroxyapatite ( $\mathrm{Pb}-\mathrm{HAP}$ ) by EDS point analysis; (e) photomicrograph of the sample RED-2m; (f) micrographs of the sample RED-2m; (g) XRD pattern of the samples RED-raw to RED-2m between $2 \theta$ of $20-38^{\circ}$; (h) FORS spectra of the samples RED-raw, RED-d1, RED-d7, RED-d28. The intensity values of each XRD pattern and FORS spectra were normalized and offset for comparison purposes.

After dispersing pigment particles in $1 \mathrm{M}$ DAP for 28 days, part of the minium pigment was found to be converted into hydroxypyromorphite (also known as lead hydroxyapatite, $\mathrm{Pb}_{10}\left(\mathrm{PO}_{4}\right)_{6}(\mathrm{OH})_{2}$, JCPDS PDF No. 01-087-2477). The color of the pigment changed from orange red to brownish red after 28 days (Figure 8c). After two months, the color was further altered to dark brown (Figure 8e). The calculated $\Delta \mathrm{E}^{*}$ value for the red lead pigment particles before and after the 28 days of immersion in DAP was found to be 30.6 (Table 1). This color change is significant and far beyond the threshold accepted in the field of conservation treatment $\left(\Delta \mathrm{E}^{*} \leq 5\right)$.

Microscopic observations of the sample RED-d28 showed that most particles remained the same, while some new elongated crystals could be detected (Figure 8d). EDS analysis on point 1 (see arrow in Figure $8 \mathrm{~d}$ ) confirmed the presence of $\mathrm{Pb}(24.65$ at \%), $\mathrm{P}(13.73$ at \%), and $\mathrm{O}(61.62$ at \%). The $\mathrm{Pb} / \mathrm{P} / \mathrm{O}$ atomic ratio was close to 5:3:13, indicating the presence of hydroxypyromorphite. After two months, a significant amount of the original pigment particles was transformed into hydroxypyromorphite (Figure 8f), which are believed to be responsible for the color change from originally red to brown. 
$\mathrm{XRD}$ analysis (Figure 8g) indicated that the raw red lead pigment (sample RED-raw) solely consisted of minium (JCPDS PDF No. 41-1493). The formation of hydroxypyromorphite (JCPDS PDF No. 8-259) was observed to begin only one day after dispersing the pigment in 1M DAP solution (sample RED-d1). After two months, the lead hydroxyapatite became a dominant phase and was identified along with the precipitates of platternite $\left(\beta-\mathrm{PbO}_{2}\right)$ and unreacted residual minium (RED-2m in Figure 8g). While phase transformations between the first day of reaction and after 28 days appeared similar, a more significant phase development was observed over a longer period (two months).

A similar dissolution-precipitation mechanism was reported elsewhere $[77,78]$. The dissolution reaction of $\mathrm{Pb}_{3} \mathrm{O}_{4}$ begins to occur at the surface of $\mathrm{Pb}_{3} \mathrm{O}_{4}$ (Reaction 2). $\mathrm{Pb}_{3} \mathrm{O}_{4}$ first releases $\mathrm{Pb}^{2+}$ species from a tetrahedrally coordinated $\mathrm{Pb}_{3}(\mathrm{II}, \mathrm{IV}) \mathrm{O}_{4}$ site through a ligand substitution, leaving unstable octahedral $\mathrm{PbO}_{2}$ fragments (octahedral arrangement hosting $\mathrm{Pb}^{4+}$ ions in the crystalline structure of $\left.\mathrm{Pb}_{3} \mathrm{O}_{4}\right)$ in the solid. The precipitation of lead hydroxyapatite $\left(\mathrm{Pb}_{10}\left(\mathrm{PO}_{4}\right)_{6}(\mathrm{OH})_{2}\right)$ observed after the immersion of $\mathrm{Pb}_{3} \mathrm{O}_{4}$ in DAP suggests a reaction between the supersaturated $\mathrm{Pb}^{2+}$ ions released during $\mathrm{Pb}_{3} \mathrm{O}_{4}$ dissolution and the phosphate $\left(\mathrm{PO}_{4}{ }^{3-}\right)$ ions delivered through the DAP solution.

$$
\mathrm{Pb}_{3} \mathrm{O}_{4}+2 \mathrm{H}_{2} \mathrm{O}_{(\mathrm{aq})} \rightarrow 2 \mathrm{~Pb}_{(\mathrm{aq})}^{2+}+\mathrm{PbO}_{2(\mathrm{~s})}+4 \mathrm{OH}_{(\mathrm{aq})}^{-}
$$

Reaction 2. Dissolution reaction of $\mathrm{Pb}_{3} \mathrm{O}_{4}$ in aqueous solution.

Following this step, two processes occur simultaneously:

(1) The unstable $\mathrm{PbO}_{2}$ fragments formed from the dissolution of $\mathrm{Pb}_{3} \mathrm{O}_{4}$ are reduced to $\mathrm{Pb}^{2+}$, as suggested by the Reaction 4 .

$$
\mathrm{PbO}_{2(\text { unstable })}+2 \mathrm{e}^{-}+2 \mathrm{H}_{2} \mathrm{O}_{(\mathrm{aq})} \rightarrow \mathrm{Pb}_{(\mathrm{aq})}^{2+}+4 \mathrm{OH}_{(\mathrm{aq})}^{-}
$$

Reaction 3. Reduction of unstable $\mathrm{PbO}_{2}$ fragment into $\mathrm{Pb}^{2+}$.

(2) The nucleation of a newly stable $\beta-\mathrm{PbO}_{2}$ from $\mathrm{Pb}^{2+}$ ions, as suggested by the Reaction 5 :

$$
\mathrm{Pb}_{(\mathrm{aq})}^{2+}+4 \mathrm{OH}_{(\mathrm{aq})}^{-} \rightarrow \mathrm{PbO}_{2(\text { stable })}+2 \mathrm{e}^{-}+2 \mathrm{H}_{2} \mathrm{O}_{(\mathrm{aq})}
$$

Reaction 4. Oxidation of $\mathrm{Pb}^{2+}$ to stable $\beta-\mathrm{PbO}_{2}$ (platternite).

Since both $\mathrm{Pb}_{3} \mathrm{O}_{4}$ and $\beta-\mathrm{PbO}_{2}$ are semiconductors, the electrons can transfer between the solid phases. The driving force for the process described is provided by the decrease in both surface and lattice free energy, which results from the dissolution of the octahedral fragment of $\mathrm{PbO}_{2}$ (labelled as $\mathrm{PbO}_{2 \text { (unstable) }}$ above) in $\mathrm{Pb}_{3} \mathrm{O}_{4}$ and the precipitation of $\beta-\mathrm{PbO}_{2}$ [77].

During the dissolution reactions (Reaction 2 to Reaction 4) that occur on the surface of $\mathrm{Pb}_{3} \mathrm{O}_{4}$, a layer of very fine particles/precipitates of $\mathrm{PbO}_{2}$ forms during the earliest dissolution stages. Once formed, $\mathrm{PbO}_{2}$ can either remain as a spectator species or be reduced, as suggested by Reaction $5[77,79,80]$, releasing more $\mathrm{Pb}^{2+}$.

$$
\mathrm{PbO}_{2(\mathrm{~s})}+\mathrm{H}_{2} \mathrm{O}(\mathrm{aq}) \rightarrow \mathrm{Pb}_{(a q)}^{2+}+2 \mathrm{OH}_{(a q)}^{-}+0.5 \mathrm{O}_{2(\mathrm{aq})}
$$

Reaction 5. Reductive dissolution of platternite $\left(\beta-\mathrm{PbO}_{2}\right)$ in aqueous solution.

However, $\mathrm{PbO}_{2}$ formed on the surface of $\mathrm{Pb}_{3} \mathrm{O}_{4}$ is likely to passivate the substrate's surface, inhibiting further dissolution of $\mathrm{Pb}_{3} \mathrm{O}_{4}$. Still, no such particles/precipitates were detected using XRD during the first month, suggesting that the formation of $\mathrm{PbO}_{2}$ might have been limited to an amount 
below the detection limit of XRD. In addition, owing to the very small porosity of the newly formed $\mathrm{PbO}_{2}$ layer on the $\mathrm{Pb}_{3} \mathrm{O}_{4}$ surface, the $\left(\mathrm{NH}_{4}\right)_{2} \mathrm{HPO}_{4}$ solution required longer time to diffuse into the $\mathrm{Pb}_{3} \mathrm{O}_{4}$ substrate. On the basis of the XRD analysis, the $\beta-\mathrm{PbO}_{2}$ phase only became detectable after two months of reaction, which suggests that the dissolution of minium continued along with the constant formation of $\mathrm{Pb}-\mathrm{HAP}$ and $\beta-\mathrm{PbO}_{2}$. However, the sudden increase in the precipitation of $\mathrm{Pb}-\mathrm{HAP}$ and the kinetics of its precipitation rate between 28 days and two months will require further investigation. No previous research into the formation mechanism of lead hydroxyapatite in a comparable system has ever been published, and therefore future research is pivotal to understanding the reaction kinetics of that system.

\section{4. $p H$ Value of the Supernantant Solutions}

The change of $\mathrm{pH}$ value of the DAP solutions as a function of time is shown in Figure 9.
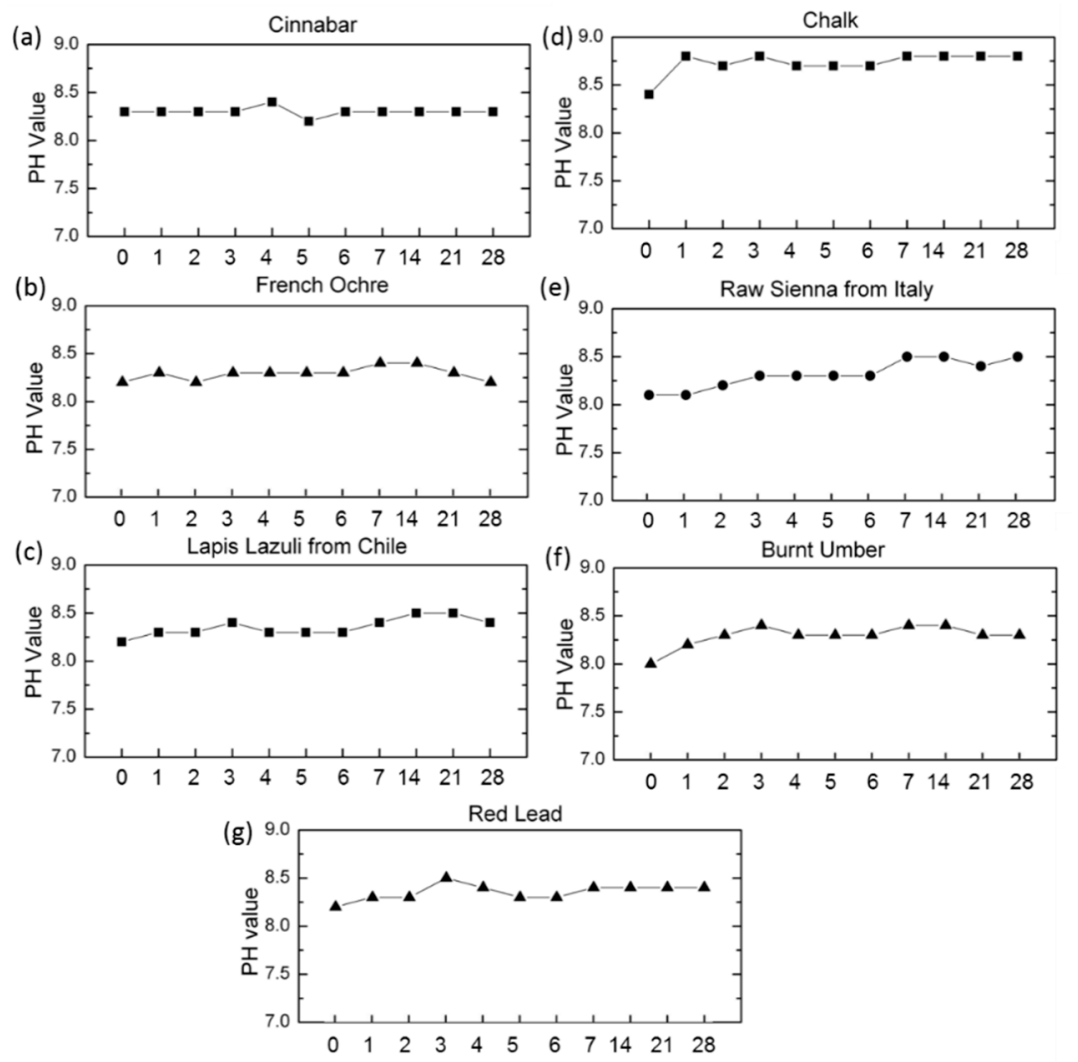

Figure 9. The change of the $\mathrm{pH}$ value of the DAP solutions with time (the number on the $\mathrm{x}$-axis means the number of days of measurement) with a standard error of \pm 0.1 .

The $\mathrm{pH}$ value of the French ochre, lapis lazuli, and cinnabar remained almost constant ( 8.3) during the first 28 days of reaction. This is consistent with the fact that no significant color, phase, or morphological changes could be observed in these pigments upon exposure to the DAP solution.

By comparing the $\mathrm{pH}$ values of the solution at day 0 and day 28 , an increase in the $\mathrm{pH}$ was observed for calcium carbonate-containing pigments, including chalk, bunt umber, raw sienna (for the latter two, as accessory mineral). This was due to the chemical reaction of calcium carbonate with DAP and the formation of phosphate phases that caused the increase in the $\mathrm{pH}$ value of the solution. A slight elevation was also observed in the $\mathrm{pH}$ value of the solution containing red lead after 28 days of reaction with DAP. This change is believed to be associated with the reaction of minium $\left(\mathrm{Pb}_{3} \mathrm{O}_{4}\right)$ with diammonium hydrogen phosphate, which leads to the formation of hydroxypyromorphite and, hence, to the corresponding increase in the $\mathrm{pH}$ value. 


\subsection{Summary of Color and Phase Changes in the Pigments}

The color values of the pigments before immersion into the DAP solutions and after 28 days of reaction with $\mathrm{DAP}$, as well as the $\Delta \mathrm{E}^{*}$ values, are listed in Table 1 . In this research, it was demonstrated that, while the color difference $\Delta \mathrm{E}^{*}$ of most pigments tested, including cinnabar (deep red), French ochre (yellow), lapis lazuli (blue), chalk (white), and raw sienna (yellow), were above the threshold detected by the human eye $\left(\Delta \mathrm{E}^{*}>2\right)$, with the exception of burnt umber (brown) which showed no detectable color change $\left(\Delta \mathrm{E}^{*}<2\right)$, they all showed $\Delta \mathrm{E}^{*}$ values below the accepted threshold $\left(\Delta \mathrm{E}^{*} \leq 5\right)$ for cultural heritage studies $[16,41-48]$. Slightly darkening $\left(-\Delta \mathrm{L}^{*}\right)$ was observed for most pigments, except raw sienna. Red lead, however, showed a significant color change, with $\Delta \mathrm{E}^{*}=30.643$, which is well above the accepted level.

Table 1. Changes in color values of the examined pigments before and after 28 days of immersion in DAP solutions.

\begin{tabular}{|c|c|c|c|c|}
\hline \multirow{2}{*}{ Pigment Name } & \multicolumn{3}{|c|}{ Value Change after 28 Days Reaction with DAP } & \multirow{2}{*}{$\begin{array}{c}\text { Change in Color } \\
\Delta \mathrm{E}^{*}\end{array}$} \\
\hline & $\Delta \mathrm{L}$ & $\Delta \mathbf{a}^{*}$ & $\Delta \mathbf{b}^{*}$ & \\
\hline Cinnabar & -1.759 & -1.874 & -2.429 & 3.5 \\
\hline French Ochre & -1.043 & -0.399 & -3.201 & 3.4 \\
\hline Lapis Lazuli & -2.844 & 1.246 & 2.773 & 4.2 \\
\hline Chalk & -4.424 & 0.508 & -2.028 & 4.9 \\
\hline Raw Sienna & 1.989 & -1.48 & -0.629 & 2.6 \\
\hline Burnt Umber & -0.865 & 1.224 & 0.709 & 1.7 \\
\hline Red lead & -10.492 & -18.057 & -22.425 & 30.6 \\
\hline
\end{tabular}

Pigments such as chalk and calcite, found as impurity or accessory mineral in some of the colored pigments, also underwent evident phase changes from calcium carbonate into calcium phosphates such as hydroxyapatite. In this case, however, these mineralogical phase changes could be considered as 'favorable', given that they provide an additional binding mechanism which is beneficial to the overall consolidation effect.

Conversely, the changes that occurred in the red lead $\left(\mathrm{Pb}_{3} \mathrm{O}_{4}\right)$ pigment can be characterized as 'non-favorable', resulting in significant color alteration from bright orange to brown (with a $\Delta \mathrm{E}^{*}=30.6$ ). Associated phase transformation from lead tetroxide into lead hydroxyapatite possibly occurred via the dissolution-precipitation mechanism described above. As a result, the exposure to DAP caused irreversible color damage in the red lead pigment. The phase transformation and significant color change of red lead caused by the DAP precursor poses significant concerns regarding this consolidation treatment for artifacts painted with this pigment, and therefore DAP-based consolidation would not be recommended.

\section{Conclusions}

The optical, physical, and chemical interactions between DAP and six pigments commonly employed in fresco applications (cinnabar, French ochre, chalk, lapis lazuli, raw sienna, and burnt umber) and one additional pigment (red lead) often used for secco applications in wall paintings and other polychrome paintings, were investigated. To study the effects of the application of the DAP precursor on the pigments' color, morphology, and mineralogy, the raw pigments (before treatment) and the reaction products after 28 days of exposure to DAP were evaluated using different and complementary characterization techniques including DM, XRD, FTIR, TGA, SEM-EDS, and FORS.

While color changes seemed to occur for most of the pigments analyzed, the majority of these were below the accepted color change threshold established for cultural heritage surface treatments. Evident phase transformations into HAP were identified only in the pigments containing calcium 
carbonate (calcite), such as the chalk pigment (main coloring phase of white pigment) and the pigments raw sienna and burnt umber, where calcite was identified as an accessory mineral. The formation of the HAP network in this context did not affect the overall color of these pigments. A significant color and phase change were only observed in the red lead pigment with the transformation of red lead (lead tetroxide) into hydroxypyromorphite. The DAP treatment on painted surfaces pigmented with red lead could therefore cause serious and irreversible damage to the artwork, both chromatically and chemically. For this reason, surface treatments using DAP solutions should be avoided when red lead is present. As demonstrated, measurable color differences and phase transformations of pigments, occurring immediately after the application of the DAP solution and after two months under controlled environmental exposure conditions, allowed for the assessment of the direct impact of the DAP solution on the color and mineralogy of pigments commonly encountered in archaeological and historic materials of cultural importance.

While this research did not directly evaluate the consolidation effect of DAP for wall paintings and other polychrome paintings, from our previous research evaluating the effects of DAP on calcium hydroxide-rich plaster layers [21] and the current research investigating the interactions between DAP and pigments, it can be inferred that for fresco wall paintings, where pigments are applied with water on the surface of a moist calcium hydroxide-rich plaster layer and are 'fixed' in place by the newly formed calcium carbonate crystals 'embedding' them into the 'surface skin' of the plaster layer, DAP precursors could also have a consolidating effect, without causing any phase or significant color change. As a proof of concept, further research, testing, and long-term monitoring will be conducted on mockups of fresco paintings and on site, where some other steps such as cleaning [81] and de-salination might be necessary prior to consolidation. Additional investigations will also be carried out on the effect of DAP on different organic binding media, a larger number of pigments, and secco wall paintings mockups to assess the extent of the use of DAP as a surface treatment for polychrome surfaces.

Author Contributions: Conceptualization, design of experiment, I.K. and X.M.; supervision and project administration: I.K., writing-original draft: X.M. and H.P., writing-review and editing: X.M., H.P., M.B., and I.K., investigation and formal analysis: X.M. and H.P., funding acquisition: I.K.

Funding: The work was supported financially by the National Science Foundation (NSF) (Award \# 1139227, Solid State and Materials Chemistry program, Division of Materials Research).

Acknowledgments: The authors would like to acknowledge the support provided by the Molecular and Nano Archaeology Laboratory at UCLA. The co-author, Hélène Pasco, was a visiting student to the Archaeomaterials Group at UCLA during 2016. The authors would acknowledge the assistance of Christian Fischer and Roxanne Radpour from the department of materials science and engineering of UCLA in FORS measurement and interpretation of the spectra.

Conflicts of Interest: The authors declare no conflict of interest.

\section{References}

1. Neiman, M.K.; Balonis, M.; Kakoulli, I. Cinnabar alteration in archaeological wall paintings: An experimental and theoretical approach. Appl. Phys. A 2015, 121, 915-938. [CrossRef]

2. Al-Emam, E.; El-Gohary, M.; El Hady, M.A. The paint layers of mural paintings at Abydos Temples-Egypt: A closer look at the materials used. Mediterr. Archaeol. Archaeom. 2015, 15, 113-121.

3. Kamel, A.M.A. Dehydration of gypsum component of plasters and stuccos in some Egyptian archaeological buildings and evaluation of $\mathrm{K}_{2} \mathrm{SO}_{4}$ activator as a consolidant. Sci. Cult. 2019, 5, 49-59.

4. Ferroni, E.; Malaguzzi-Valerj, V.; Rovida, G. Experimental study by diffraction of heterogeneous systems as a preliminary to the proposal of a technique for the restoration of gypsum polluted murals. In Proceedings of the Reports, Plenary Meeting, Amsterdam, Netherlands, 1969-ICOM Committee for Conservation, Amsterdam, The Netherlands, 15-19 September 1969.

5. Matteini, M. In Review: An Assessment of Florentine Methods of Wall Painting Conservation Based. In The Conservation of Wall Paintings; Getty Conservation Institute: Los Angeles, CA, USA, 1991; pp. 137-148.

6. Giorgi, R.; Dei, L.; Baglioni, P. A New Method for Consolidating Wall Paintings Based on Dispersions of Lime in Alcohol. Stud. Conserv. 2000, 45, 154-161. 
7. Baglioni, P.; Carretti, E.; Dei, L.; Giorgi, R. Nanotechnology in Wall Painting Conservation; IOS Press Ohmsha: Amsterdam, The Netherlands, 2003.

8. Baglioni, P.; Giorgi, R. Soft and hard nanomaterials for restoration and conservation of cultural heritage. Soft Matter 2006, 2, 293-303. [CrossRef]

9. Giorgi, R.; Ambrosi, M.; Toccafondi, N.; Baglioni, P. Nanoparticles for cultural heritage conservation: Calcium and barium hydroxide nanoparticles for wall painting consolidation. Chem. A Eur. J. 2010, 16, 9374-9382. [CrossRef] [PubMed]

10. Giorgi, R.; Baglioni, M.; Berti, D.; Baglioni, P. New Methodologies for the Conservation of Cultural Heritage: Micellar Solutions, Microemulsions, and Hydroxide Nanoparticles. Acc. Chem. Res. 2010, 43, 695-704. [CrossRef] [PubMed]

11. Chelazzi, D.; Poggi, G.; Jaidar, Y.; Toccafondi, N.; Giorgi, R.; Baglioni, P. Hydroxide nanoparticles for cultural heritage: Consolidation and protection of wall paintings and carbonate materials. J. Colloid Interface Sci. 2013, 392, 42-49. [CrossRef] [PubMed]

12. Balonis, M. Mineral Inorganic Treatments. In The Encyclopedia of Archaeological Sciences; Varela, S.L.L., Ed.; Wiley-Blackwell: Hoboken, NJ, USA, 2018.

13. Borgia, G.C.; Camaiti, M.; Cerri, F.; Fantazzini, P.; Piacenti, F. Hydrophobic Treatments for Stone Conservation: Influence of the Application Method on Penetration, Distribution and Efficiency. Stud. Conserv. 2003, 48, 217-226. [CrossRef]

14. Liu, Q.; Zhang, B.J. Synthesis and Characterization of a Novel Biomaterial for the Conservation of Historic Stone Buildings and Sculptures. Adv. Mater. Sci. Technol. 2011, 675-677, 317-320. [CrossRef]

15. Yang, F.; Zhang, B.; Liu, Y.; Wei, G.; Zhang, H.; Chen, W.; Xu, Z. Biomimic conservation of weathered calcareous stones by apatite. New J. Chem. 2011, 35, 887-892. [CrossRef]

16. Sassoni, E.; Naidu, S.; Scherer, G.W. The use of hydroxyapatite as a new inorganic consolidant for damaged carbonate stones. J. Cult. Herit. 2011, 12, 346-355. [CrossRef]

17. Sassoni, E.; Naidu, S.; Scherer, G.W. Preliminary results of the use of hydroxyapatite as a consolidant for carbonate stones. In Proceedings of the Materials Research Society Fall Meeting 2010, Boston, MA, USA, 29 November-2 December 2010.

18. Matteini, M.; Rescic, S.; Fratini, F.; Botticelli, G. Ammonium Phosphates as Consolidating Agents for Carbonatic Stone Materials Used in Architecture and Cultural Heritage: Preliminary Research. Int. J. Archit. Herit. 2011, 5, 717-736. [CrossRef]

19. Sassoni, E.; Franzoni, E.; Scherer, G.W.; Naidu, S. Consolidation of a porous limestone by means of a new treatment based on hydroxyapatite. In Proceedings of the 12th International Congress on Deterioration and Conservation of Stone, New York, NY, USA, 21-25 October 2012.

20. Sassoni, E.; Franzoni, E.; Pigino, B.; Scherer, G.W.; Naidu, S. Consolidation of calcareous and siliceous sandstones by hydroxyapatite: Comparison with a TEOS-based consolidant. J. Cult. Herit. 2013, 14, e103-e108. [CrossRef]

21. Balonis-Sant, M.; Ma, X.; Kakoulli, I. Preliminary Results on Biomimetic Methods Based on Soluble Ammonium Phosphate Precursors for the Consolidation of Archaeological Wall Paintings. In Archaeological Chemistry VIII; ACS Symposium Series; American Chemical Society: Washington, DC, USA, 2013; pp. $420-447$.

22. Sassoni, E.; Franzoni, E. Sugaring marble in the Monumental Cemetery in Bologna (Italy): Characterization of naturally and artificially weathered samples and first results of consolidation by hydroxyapatite. Appl. Phys. A 2014, 117, 1893-1906. [CrossRef]

23. Sassoni, E.; Graziani, G.; Franzoni, E. Repair of sugaring marble by ammonium phosphate: Comparison with ethyl silicate and ammonium oxalate and pilot application to historic artifact. Mater. Des. 2015, 88, 1145-1157. [CrossRef]

24. Ma, X.; Balonis, M.; Pasco, H.; Toumazou, M.; Counts, D.; Kakoulli, I. Evaluation of hydroxyapatite effects for the consolidation of a Hellenistic-Roman rock-cut chamber tomb at Athienou-Malloura in Cyprus. Constr. Build. Mater. 2017, 150, 333-344. [CrossRef]

25. Sassoni, E. Hydroxyapatite and Other Calcium Phosphates for the Conservation of Cultural Heritage: A Review. Materials 2018, 11, 557. [CrossRef]

26. Kamiya, M.; Hatta, J.; Shimida, E.; Ikuma, Y.; Yoshimura, M.; Monma, H. AFM analysis of initial stage of reaction between calcite and phosphate. Mater. Sci. Eng. B 2004, 111, 226-231. [CrossRef] 
27. Matteini, M. Inorganic treatments for cleaning, consolidation and protection of mural paintings: Tradition and innovation. In Proceedings of the Works of Art\&Conservation Science Today, Thessaloniki, Greece, 26-28 November 2010.

28. Scherer, G.W.; Flatt, R.; Wheeler, G. Materials science research for the conservation of sculpture and monuments. Mrs Bull. 2001, 26, 44-50. [CrossRef]

29. Wang, Q.; Dove, S.; Shearman, F.; Smirniou, M. Evaluation of methods of chloride ion concentration determination and effectiveness of desalination treatments using sodium hydroxide and alkaline sulphite solutions. Conservator 2008, 31, 67-74. [CrossRef]

30. Dorozhkin, S.V. Calcium orthophosphates in nature, biology and medicine. Materials 2009, 2, $399-498$. [CrossRef]

31. Lide, D.R. CRC Handbook of Chemistry and Physics, 85th ed.; CRC Press: Boca Raton, FL, USA, 2004.

32. Mathew, M.; Takagi, S. Structures of Biological Minerals in Dental Research. J. Res. Natl. Inst. Stand. Technol. 2001, 106, 1035-1044. [CrossRef]

33. Maslen, E.; Streltsov, V.; Streltsova, N.; Ishizawa, N. Electron density and optical anisotropy in rhombohedral carbonates. III. Synchrotron X-ray studies of $\mathrm{CaCO}_{3}, \mathrm{MgCO}_{3}$ and $\mathrm{MnCO}_{3}$. Acta Crystallogr. Sect. B Struct. Sci. 1995, 51, 929-939. [CrossRef]

34. Chow, L. Solubility of calcium phosphates. In Octacalcium Phosphate; Karger Publishers: Berlin, Germany, 2001; Volume 18, pp. 94-111.

35. Eighmy, T.T.; Eusden, J.D. Phosphate stabilization of municipal solid waste combustion residues: Geochemical principles. Geol. Soc. Lond. Spec. Publ. 2004, 236, 435-473. [CrossRef]

36. Valsami-Jones, E.; Ragnarsdottir, K.; Putnis, A.; Bosbach, D.; Kemp, A.; Cressey, G. The dissolution of apatite in the presence of aqueous metal cations at $\mathrm{pH}$ 2-7. Chem. Geol. 1998, 151, 215-233. [CrossRef]

37. Chou, L.; Garrels, R.M.; Wollast, R. Comparative study of the kinetics and mechanisms of dissolution of carbonate minerals. Chem. Geol. 1989, 78, 269-282. [CrossRef]

38. Salama, K.K.; Ali, M.F.; El-Sheikh, S.M. The different influence on nano materials on pigments. Sci. Cult. 2018, 4, 1-7.

39. McLaren, K. XIII-The development of the CIE $1976\left(\mathrm{~L}^{*} \mathrm{a}^{*} \mathrm{~b}^{*}\right)$ uniform colour space and colour-difference formula. J. Soc. Dye. Colour. 1976, 92, 338-341. [CrossRef]

40. Wojciech Mokrzycki, M.T. Color difference Delta E-A survey. Mach. Graph. Vis. 2011, 20, $383-411$.

41. Miliani, C.; Velo-Simpson, M.L.; Scherer, G.W. Particle-modified consolidants: A study on the effect of particles on sol-gel properties and consolidation effectiveness. J. Cult. Herit. 2007, 8, 1-6. [CrossRef]

42. Sasse, H.R.; Snethlage, R. Methods for the Evaluation of Stone Conservation Treatments. In Report of Dahlem Workshop on Saving our Architectural Heritage-Conservation of Historic Stone Structures; Baer, N.S., Snethlage, R., Eds.; John Wiley \& Sons: Berlin, Germany, 1996; pp. 223-227.

43. Duchêne, S.; Detalle, V.; Favaro, M.; Ossola, F.; Tomasin, P.; De Zorzi, C.; El Habra, N. Nanomaterials for consolidation of marble and wall paintings. In Proceedings of the 12th International Congress on the Deterioration and Conservation of Stone, New York, NY, USA, 22-26 October 2012.

44. Natali, I.; Tomasin, P.; Becherini, F.; Bernardi, A.; Ciantelli, C.; Favaro, M.; Favoni, O.; Pérez, V.J.F.; Olteanu, I.D.; Sanchez, M.D.R. Innovative consolidating products for stone materials: Field exposure tests as a valid approach for assessing durability. Herit. Sci. 2015, 3, 6. [CrossRef]

45. Martinez, P.; Soto, M.; Zunino, F.; Stuckrath, C.; Lopez, M. Effectiveness of tetra-ethyl-ortho-silicate (TEOS) consolidation of fired-clay bricks manufactured with different calcination temperatures. Constr. Build. Mater. 2016, 106, 209-217. [CrossRef]

46. Becherini, F.; Durante, C.; Bourguignon, E.; Vigni, M.L.; Detalle, V.; Bernardi, A.; Tomasin, P. Aesthetic compatibility assessment of consolidants for wall paintings by means of multivariate analysis of colorimetric data. Chem. Cent. J. 2018, 12, 98. [CrossRef] [PubMed]

47. Bourguignon, E.; Tomasin, P.; Detalle, V.; Vallet, J.-M.; Labouré, M.; Olteanu, I.; Favaro, M.; Chiurato, M.A.; Bernardi, A.; Becherini, F. Calcium alkoxides as alternative consolidants for wall paintings: Evaluation of their performance in laboratory and on site, on model and original samples, in comparison to conventional products. J. Cult. Herit. 2018, 29, 54-66. [CrossRef]

48. García, O.; Malaga, K. Definition of the procedure to determine the suitability and durability of an anti-graffiti product for application on cultural heritage porous materials. J. Cult. Herit. 2012, 13, 77-82. [CrossRef] 
49. Aceto, M.; Agostino, A.; Fenoglio, G.; Idone, A.; Gulmini, M.; Picollo, M.; Ricciardi, P.; Delaney, J.K. Characterisation of colourants on illuminated manuscripts by portable fibre optic UV-visible-NIR reflectance spectrophotometry. Anal. Methods 2014, 6, 1488-1500. [CrossRef]

50. Bougeard, D.; Smirnov, K.S.; Geidel, E. Vibrational spectra and structure of kaolinite: A computer simulation study. J. Phys. Chem. B 2000, 104, 9210-9217. [CrossRef]

51. Genestar, C.; Pons, C. Earth pigments in painting: Characterisation and differentiation by means of FTIR spectroscopy and SEM-EDS microanalysis. Anal. Bioanal. Chem. 2005, 382, 269-274. [CrossRef]

52. Spence, A.; Kelleher, B.P. FT-IR spectroscopic analysis of kaolinite-microbial interactions. Vib. Spectrosc. 2012, 61, 151-155. [CrossRef]

53. Muüller, C.M.; Molinelli, A.; Karlowatz, M.; Aleksandrov, A.; Orlando, T.; Mizaikoff, B. Infrared attenuated total reflection spectroscopy of quartz and silica micro-and nanoparticulate films. J. Phys. Chem. C 2011, 116, 37-43. [CrossRef]

54. Müller, C.M.; Pejcic, B.; Esteban, L.; Delle Piane, C.; Raven, M.; Mizaikoff, B. Infrared attenuated total reflectance spectroscopy: An innovative strategy for analyzing mineral components in energy relevant systems. Sci. Rep. 2014, 4, 6764. [CrossRef]

55. Saikia, B.J.; Parthasarathy, G.; Sarmah, N. Fourier transform infrared spectroscopic estimation of crystallinity in $\mathrm{SiO}_{2}$ based rocks. Bull. Mater. Sci. 2008, 31, 775-779. [CrossRef]

56. Bikiaris, D.; Daniilia, S.; Sotiropoulou, S.; Katsimbiri, O.; Pavlidou, E.; Moutsatsou, A.; Chryssoulakis, Y. Ochre-differentiation through micro-Raman and micro-FTIR spectroscopies: Application on wall paintings at Meteora and Mount Athos, Greece. Spectrochim. Acta Part A Mol. Biomol. Spectrosc. 2000, 56, 3-18. [CrossRef]

57. Gautier, M.; Muller, F.; Le Forestier, L.; Beny, J.-M.; Guégan, R. NH 4 -smectite: Characterization, hydration properties and hydro mechanical behaviour. Appl. Clay Sci. 2010, 49, 247-254. [CrossRef]

58. Pironon, J.; Pelletier, M.; De Donato, P.; Mosser-Ruck, R. Characterization of smectite and illite by FTIR spectroscopy of interlayer $\mathrm{NH}_{4}{ }^{+}$cations. Clay Miner. 2003, 38, 201-211. [CrossRef]

59. Mortland, M.; Fripiat, J.; Chaussidon, J.; Uytterhoeven, J. Interaction between ammonia and the expanding lattices of montmorillonite and vermiculite. J. Phys. Chem. 1963, 67, 248-258. [CrossRef]

60. Elias, M.; Chartier, C.; Prévot, G.; Garay, H.; Vignaud, C. The colour of ochres explained by their composition. Mater. Sci. Eng. B 2006, 127, 70-80. [CrossRef]

61. Dai, Q.; Dong, F.; Zhao, Y.; Deng, J.; Lu, J. Reciprocity effect between silicate bacterium and wollastonite. In Proceedings of the 11th International Congress for Applied Mineralogy (ICAM), Mianyang, China, 5-10 July 2013; pp. 59-69.

62. Sitarz, M.; Mozgawa, W.; Handke, M. Vibrational spectra of complex ring silicate anions-Method of recognition. J. Mol. Struct. 1997, 404, 193-197. [CrossRef]

63. Paluszkiewicz, C.; Blażewicz, M.; Podporska, J.; Gumuła, T. Nucleation of hydroxyapatite layer on wollastonite material surface: FTIR studies. Vib. Spectrosc. 2008, 48, 263-268. [CrossRef]

64. Salvadó, N.; Butí, S.; Aranda, M.A.; Pradell, T. New insights on blue pigments used in 15th century paintings by synchrotron radiation-based micro-FTIR and XRD. Anal. Methods 2014, 6, 3610-3621. [CrossRef]

65. Gunasekaran, S.; Anbalagan, G.; Pandi, S. Raman and infrared spectra of carbonates of calcite structure. J. Raman Spectrosc. 2006, 37, 892-899. [CrossRef]

66. Koutsopoulos, S. Synthesis and characterization of hydroxyapatite crystals: A review study on the analytical methods. J. Biomed. Mater. Res. 2002, 62, 600-612. [CrossRef] [PubMed]

67. Wang, L.; Nancollas, G.H. Calcium orthophosphates: Crystallization and dissolution. Chem. Rev. 2008, 108, 4628-4669. [CrossRef] [PubMed]

68. Miers, H.A. Mineralogy: An Introduction to the Scientific Study of Minerals; Macmillan and Company: London, UK, 1902.

69. Liu, Y.; Wang, A.; Freemen, J. Raman, MIR, and NIR spectroscopic study of calcium sulfates: Gypsum, bassanite, and anhydrite. In Proceedings of the Lunar and Planetary Science Conference, Woodlands, TX, USA, 23-27 March 2009; p. 2128.

70. Takahashi, H.; Maehara, I.; Kaneko, N. Infrared reflection spectra of gypsum. Spectrochim. Acta Part A Mol. Spectrosc. 1983, 39, 449-455. [CrossRef]

71. Martin, M.A.; Childers, J.W.; Palmer, R.A. Fourier Transform Infrared Photoacoustic Spectroscopy characterization of sulfur-oxygen species resulting from the reaction of $\mathrm{SO}_{2}$ with $\mathrm{CaO}$ and $\mathrm{CaCO}_{3}$. Appl. Spectrosc. 1987, 41, 120-126. [CrossRef] 
72. Madejova, J.; Komadel, P. Baseline studies of the clay minerals society source clays: Infrared methods. Clays Clay Miner. 2001, 49, 410-432. [CrossRef]

73. Ruan, H.; Frost, R.L.; Kloprogge, J.T.; Duong, L. Infrared spectroscopy of goethite dehydroxylation: III. FT-IR microscopy of in situ study of the thermal transformation of goethite to hematite. Spectrochim. Acta Part A Mol. Biomol. Spectrosc. 2002, 58, 967-981. [CrossRef]

74. Blanchard, M.; Balan, E.; Giura, P.; Béneut, K.; Yi, H.; Morin, G.; Pinilla, C.; Lazzeri, M.; Floris, A. Infrared spectroscopic properties of goethite: Anharmonic broadening, long-range electrostatic effects and $\mathrm{Al}$ substitution. Phys. Chem. Miner. 2014, 41, 289-302. [CrossRef]

75. Parfitt, R.L.; Russell, J.D.; Farmer, V.C. Confirmation of the surface structures of goethite $(\alpha-\mathrm{FeOOH})$ and phosphated goethite by infrared spectroscopy. J. Chem. Soc. Faraday Trans. 1 Phys. Chem. Condens. Phases 1976, 72, 1082-1087. [CrossRef]

76. Salama, W.; El Aref, M.; Gaupp, R. Spectroscopic characterization of iron ores formed in different geological environments using FTIR, XPS, Mössbauer spectroscopy and thermoanalyses. Spectrochim. Acta Part A Mol. Biomol. Spectrosc. 2015, 136, 1816-1826. [CrossRef] [PubMed]

77. Guo, D.; Robinson, C.; Herrera, J.E. Mechanism of dissolution of minium $\left(\mathrm{Pb}_{3} \mathrm{O}_{4}\right)$ in water under depleting chlorine conditions. Corros. Sci. 2016, 103, 42-49. [CrossRef]

78. Kang, Z.; Machesky, L.; Eick, H.; Eyring, L. The solvolytic disproportionation of mixed-valence compounds: III. $\mathrm{Pb}_{3} \mathrm{O}_{4}$. J. Solid State Chem. 1988, 75, 73-89. [CrossRef]

79. Xie, Y. Dissolution, Formation, and Transformation of the Lead Corrosion Product PbO2: Rates and Mechanisms of Reactions that Control Lead Release in Drinking Water Distribution Systems; Washington University in St. Louis: St. Louis, MO, USA, 2010.

80. Lin, Y.-P.; Valentine, R.L. The release of lead from the reduction of lead oxide $\left(\mathrm{PbO}_{2}\right)$ by natural organic matter. Environ. Sci. Technol. 2008, 42, 760-765. [CrossRef] [PubMed]

81. El-Sheikh, S.M.; Ali, M.F.; Salama, K.K. Low cost pulps with microemulsions for cleaning of fresco painting surfaces. Sci. Cult. 2017, 3, 41-46.

(C) 2019 by the authors. Licensee MDPI, Basel, Switzerland. This article is an open access article distributed under the terms and conditions of the Creative Commons Attribution (CC BY) license (http://creativecommons.org/licenses/by/4.0/). 